Biochemical Journal: this is an Accepted Manuscript, not the final Version of Record. You are encouraged to use the Version of Record that, when published, will replace this version. The most up-to-date version is available at http://dx.doi.org/10.1042/BCJ20170578. Please cite using the DOI $10.1042 / \mathrm{BCJ} 20170578$

\title{
Activation of tissue plasminogen activator by metastasis-inducing S100P protein
}

Christopher Clarke ${ }^{1 *}$, Stephane R. Gross ${ }^{2 *}$, Thamir M. Ismail ${ }^{1 *}$, Philip S. Rudland ${ }^{1}$, Morteta Al-Medhtiy ${ }^{1,3}$, Michael Santangeli ${ }^{1}$, and Roger Barraclough ${ }^{1}$

${ }^{1}$ Institute of Integrative Biology, University of Liverpool, Biosciences Building, Crown Street, Liverpool L69 7ZB, UK

${ }^{2}$ School of Life and Health Sciences, Main Building, Aston University, Aston Triangle, Birmingham B4 7ET, UK

${ }^{3}$ Department of Anatomy and Histology, Faculty of Veterinary Medicine, University of Kufa, Kufa, Iraq.

* These authors contributed equally to the manuscript.

Correspondence:

Roger Barraclough, brb@liverpool.ac.uk

S100P protein in human breast cancer cells is associated with reduced patient survival and, in a model system of metastasis, it confers a metastatic phenotype upon benign mammary tumour cells. S100P protein possesses a C-terminal lysine residue. Using a multiwell in vitro assay, $\mathrm{S} 100 \mathrm{P}$ is now shown for the first time to exhibit a strong, C-terminal-lysinedependent activation of tissue plasminogen activator (tPA), but not of urokinase-catalysed plasminogen activation. The presence of $10 \mu \mathrm{M}$ calcium ions stimulates tPA activation of plasminogen 2-fold in an S100P-dependent manner. S100P physically interacts with both plasminogen and tPA in vitro, but not with urokinase. Cells constitutively expressing S100P exhibit detectable S100P protein on the cell surface and S100P-containing cells show enhanced activation of plasminogen compared with S100P-negative control cells. $\mathrm{S} 100 \mathrm{P}$ shows $C$-terminal-lysine-dependent enhancement of cell invasion. An S100P antibody, when added to the culture medium, reduced the rate of invasion of wild-type S100P-expressing cells, but not of cells expressing mutant S100P proteins lacking the $C$ terminal lysine, suggesting that S100P functions outside the cell. The protease inhibitors, aprotinin or $\alpha$-2-antiplasmin, reduced the invasion of S100P-expressing cells, but not of S100P-negative control cells, nor cells expressing S100P protein lacking the $C$-terminal lysine. It is proposed that activation of tissue plasminogen activator via the $C$-terminal lysine of S100P contributes to the enhancement of cell invasion by S100P and thus potentially to its metastasis-promoting activity.

Short title: Plasminogen activation by S100P protein

Key words:

S100P, plasminogen activator, cell invasion.

Abbreviations:

ANOVA, analysis of variance; BSA, bovine serum albumin; CI, confidence interval; DMEM, Dulbecco's modified Eagle's medium; eEF1A, eukaryotic elongation factor 1A; ELISA, enzyme-linked immunosorbent assay; PBS, phosphate-buffered saline; r, recombinant; SEC-MALS, size exclusion chromatography multi-angle light scattering; 
SPR, surface plasmon resonance; tPA, tissue plasminogen activator; uPA, urokinasetype plasminogen activator; 6-ACA, 6-aminocaproic acid.

\section{Introduction}

Certain S100 proteins, S100A4 and S100P, when present individually in patients' cancers are associated with reduced patient survival [1-8], an association that is a likely consequence of the ability of these proteins to confer upon cells a metastatic phenotype. For S100A4, its elevated expression in two independent transgenic mouse models induces metastasis of oncogene-induced, non-metastatic tumours in the mammary gland $[9,10]$. In an in vivo model system of breast cancer metastasis, expression of either S100A4 [11] or S100P [7] in a non-metastatic benign rat mammary tumour cell line results in the induction of a metastatic phenotype. It is now evident that intracellular S100A4 can enhance multiple properties contributing to the induction of a metastatic phenotype, including the activation of cell migration $[12,13]$, arising from a specific interaction with non-muscle myosin isoform A [14], alteration in apoptotic capability, by interaction with the tumour suppressor protein, p53 [15] and enhanced invasion through the stimulation of expression of metalloproteinases [16]. Furthermore, extracellular S100A4, as high molecular weight associations, has been reported to act on endothelial cells to induce angiogenesis [17] and to activate plasminogen activators in vitro by a mechanism similar to that of S100A10 [18].

S100A10, a subunit of the annexin 2 tetramer, promotes plasminogen activation when its C-terminal lysines are displayed at the cell surface [19], particularly on endothelial cells [20]. The displayed C-terminal lysine residues interact with lysine-binding Kringle domains in plasminogen and tissue plasminogen activator proteins in the extracellular milieu [21]. In macrophages, this interaction leads to enhanced invasion [22].

The molecular mechanisms whereby S100P induces a metastatic phenotype are much less well understood than for S100A4. In common with other S100 proteins, the S100P monomer contains a high and a low affinity calcium binding site [23]. The low affinity calcium binding site can bind $\mathrm{Mg}^{2+}$ and the high affinity calcium binding site also binds $\mathrm{Zn}^{2+}$ [24], although interaction is unlikely at recently-determined free intracellular (cytoplasmic) and extracellular concentrations of zinc [25, 26] and magnesium [27] ions. Using analytical ultracentrifugation experiments, it has been shown that the oligomeric state of the S100P molecule varies according to the calcium concentration [24].

S100P has been reported to interact with the cell-membrane-actin-cross linking protein, Ezrin [28], and the cytoskeletal protein IQGAP1 [29], however, any consequences of such interaction in the context of cancer metastasis or even cell invasion are so far unknown. S100P interacts specifically with, and causes dissociation of, non-muscle myosin II isoforms A and $\mathrm{C}$, with a consequential reduction in vinculin-containing focal adhesions, an increase in cell motility and reduced cell adhesion [30]. The likelihood is that, as with S100A4, S100P exerts its metastasis-inducing properties via a number of separate pathways, including cell invasion. However, apart from an association of S100P with the RAGE receptor and epithelial mesenchymal transition [31], none of the present protein targets of S100P have been reported to have an S100P-associated role in the cellular invasion process. Since S100P contains a $C$-terminal lysine, it is possible that one such pathway is the activation of plasminogen. In this paper, we show for the 
first time that $\mathrm{S} 100 \mathrm{P}$ can activate plasminogen activators and that this activity contributes to the metastasis-associated biological property of cell invasion in S100Pexpressing cells with metastatic potential [7].

\section{Materials and Methods}

\section{Cell lines and pools}

The benign rat mammary tumour cell line, Rama 37 [32], was used in the present experiments because expression of S100P in these cells has been shown to confer a metastatic phenotype [7]. Rama 37 cells were transfected, as described previously [33] with empty PBK-CMV plasmid expression vector or PBK-CMV vector containing a cDNA encoding wild type human S100P protein, or a mutant S100P protein in which the $C$-terminal lysine has been replaced with alanine, designated K95A, or a mutant S100P protein lacking the $C$-terminal lysine, designated $\Delta \mathrm{K} 95$. Cell clones and pools were isolated as described previously [33] and cultured in Dulbecco's modified Eagle's medium $(\mathrm{DMEM})$ with $10 \%(\mathrm{v} / \mathrm{v})$ foetal calf serum, as described previously [11] with $1 \mathrm{mg} / \mathrm{mL}$ G418 included for all transfected cells. These cloned and pooled cell lines exhibit similar levels of S100P as determined by Western blotting (Supplementary information 1). In some experiments, an existing S100P inducible system, Rama 37-T25 was utilised [30], with cells cultured as above and wild type human S100P protein production being induced with $1 \mu \mathrm{g} / \mathrm{mL}$ doxycycline for $24 \mathrm{~h}$.

Transwell cell invasion assays were carried out using $8 \mu \mathrm{m}$ pore-size BioCoat Matrigel Invasion plates (BD Biosciences, MA). The chambers were rehydrated for at least $2 \mathrm{~h}$ by adding warm, serum-free DMEM to the interior of the upper chambers and to the lower wells. Following rehydration, the wells were filled with $750 \mu \mathrm{L}$ of DMEM containing 5\% $(\mathrm{v} / \mathrm{v})$ foetal calf serum. The upper chambers were filled with $500 \mu \mathrm{L}$ of the cell suspension containing 25,000 cells in DMEM with $1 \%(\mathrm{v} / \mathrm{v})$ serum and were inserted into the wells. The plates were incubated for $22 \mathrm{~h}$ in a humidified tissue culture incubator at $37^{\circ} \mathrm{C}$ with a $10 \%(\mathrm{v} / \mathrm{v}) \mathrm{CO}_{2}$ atmosphere. The non-invading cells on the upper surface were removed by gentle, but firm, scrubbing using a cotton-tipped swab. The invading cells on the lower surface of the membrane were stained by Diff-Quik solution, the membrane was removed using a sharp scalpel blade and the cells were counted using a light microscope [34].

\section{Detection of S100P on the cell surface by enzyme-linked immunosorbent assay} For analysis of extracellular and cell surface-bound S100P, quantification of the protein was carried out using an adapted enzyme-linked immunosorbent assay (ELISA) directly on living cells, as previously described [35]. Briefly 10,000 cells were seeded in 96well plates and grown for $48 \mathrm{~h}$. To assess the presence of S100P or eukaryotic elongation factor 1A (eEF1A) as an intracellular marker in both intracellular and extracellular fractions, cells were either incubated in the presence of antibody for $1 \mathrm{~h}$ prior to fixing, or fixed prior to antibody addition, or fixed, permeabilised and incubated with antibody directed against either S100P (R\&D Systems) or eEF1A (Merck Millipore). Fixation was carried out using 3.7\% (w/v) paraformaldehyde in phosphatebuffered saline (PBS) for $20 \mathrm{~min}$ at room temperature, whilst permeabilisation was achieved by incubating cells in $0.5 \%(\mathrm{v} / \mathrm{v})$ Triton-X100 in PBS for $20 \mathrm{~min}$ at room temperature. Following the incubation with the primary antibody, wells were washed with blocking buffer $(5 \%(\mathrm{w} / \mathrm{v})$ dried skimmed milk in PBS, $\mathrm{pH}$ 7.4) prior to incubation with an appropriate horseradish-peroxidase-labelled secondary antibody for $2 \mathrm{~h}$ at room temperature. After subsequent washing, the reaction was developed using o- 
phenylenediamine dihydrochloride substrate (Sigma, UK) and absorbance read at 450 nm using a multiwell plate reader.

\section{Production of recombinant wild type and mutant S100P proteins}

His-tagged wild type and mutant recombinant (r)S100P proteins were produced in BL21 (DE3) E. coli cells (Thermo Fisher), as described previously [33]. rS100P-positive fractions eluted from a HisTrap column (GE Healthcare) were buffer-exchanged into 50 $\mathrm{mM}$ Tris- $\mathrm{HCl} \mathrm{pH} 8.0,250 \mathrm{mM} \mathrm{NaCl}$ and the tag cleaved by addition of thrombin- agarose resin (Sigma) for $20 \mathrm{~h}$ at room temperature. Residual uncleaved protein and the cleaved His tag were removed by passing the supernatant from the cleavage reaction through a HisTrap column, and the flow-through, containing $\mathrm{rS100P}$ protein without the His tag, was then passed down a Superdex ${ }^{\circledR} 75$ gel filtration column (GE Healthcare) into $50 \mathrm{mM}$ HEPES (pH 7.4), $250 \mathrm{mM} \mathrm{NaCl}$ (Supplementary information 2). Size Exclusion Chromatography-Multi-Angle Light Scattering (SEC-MALS) was carried out as described previously [36].

\section{Plasminogen activation assays in vitro}

Assays were performed as described by Semov et al. [18]. rS100P protein, $100 \mathrm{nM}$ Glu-plasminogen (Millipore) and $125 \mu \mathrm{M}$ chromozyme PL (Roche) were pre-incubated for $60 \mathrm{~min}$ at room temperature in a reaction buffer consisting of $50 \mathrm{mM}$ Tris- $\mathrm{HCl}(\mathrm{pH}$ 7.4) and $100 \mathrm{mM} \mathrm{NaCl}$, with or without $\mathrm{CaCl}_{2}$. The reaction was initiated by the addition of tissue Plasminogen Activator (tPA) (Millipore) or urokinase-type Plasminogen Activator (uPA) (Millipore) as indicated in the figure legends and activation of plasminogen was measured by an increase in optical density at $405 \mathrm{~nm}$ for $2 \mathrm{~h}$, at 2-min intervals.

For measurement of the activation of plasminogen activators by cultured cells, 2,000 cells were seeded in each well of a Corning 24-flat-bottomed-well plate and allowed to attach for $24 \mathrm{~h}$. Attached cells were washed twice in PBS and incubated in $100 \mathrm{nM}$ Glu-plasminogen and $125 \mu \mathrm{M}$ chromozyme PL (Roche) in PBS. Plasminogen activation was initiated by the addition of tPA in a final volume of $500 \mu \mathrm{L}$ for $1 \mathrm{~h}$. The activation of plasminogen by tPA was measured by the increase in optical density at 405 nm of samples withdrawn at 10-min intervals.

\section{Interaction between S100P, plasminogen and plasminogen activators}

Surface plasmon resonance (SPR) experiments were conducted in a Biacore X-100 instrument (GE Healthcare). Proteins were immobilised on CM5 chips, using amine coupling chemistry, as described previously [37]. Experiments were carried out using a running buffer consisting of $10 \mathrm{mM}$ HEPES (pH 7.4), $150 \mathrm{mM} \mathrm{NaCl}$, added $\mathrm{CaCl}_{2}$ as specified in the Results section and $1 \mathrm{mg} / \mathrm{mL}$ carboxymethyl dextran (Sigma), at a flow rate of $30 \mu \mathrm{L} / \mathrm{min}$ at $25^{\circ} \mathrm{C}$. Binding kinetics were studied using multi-cycle kinetic analysis, with surfaces regenerated using $1 \mathrm{mM}$ EGTA between cycles. When used, 6aminocaproic acid (6-ACA) and EGTA were added to the analyte samples only, not to the running buffer. Binding constants were calculated using BiaEvaluation software 2.0 (GE Healthcare). Association and dissociation of S100P with tPA occurred very rapidly, and thus $K_{\mathrm{d}}$ values for tPA interactions were determined at equilibrium. Gluplasminogen binding constants were assessed using standard kinetic analysis, as described previously [33]. 
Statistical analyses

Stats Direct software version 3.0.181 was used for statistical analyses. For single comparisons, Student's t-test was used; for multiple comparisons, Analysis of Variance with Bonferroni post-hoc test was used.

\section{Results}

\section{Plasminogen activator activation by $\mathrm{S100P}$ in vitro}

S100A10 and S100A4 have been reported to activate plasminogen activators by virtue of their $C$-terminal lysine residues $[18,38]$. Since $S 100 \mathrm{P}$ also possesses a $C$-terminal lysine, we tested whether $\mathrm{rS100P}$ could regulate tPA-catalysed plasminogen activation using a multiwell assay. The production of active plasmin from Glu-plasminogen was monitored over time, by the appearance of a coloured product from a plasmin-specific substrate, as described in Materials and Methods, using a buffer containing $5 \mathrm{mM}$ calcium ions. In the absence of tPA, no plasmin activity was detected either without (Figure 1, panels A, B or C) or with (not shown) $1 \mu \mathrm{M} \mathrm{rS100P.} \mathrm{The} \mathrm{addition} \mathrm{of} \mathrm{excess}$ tPA led to the generation of plasmin activity from Glu-plasminogen after a short lag period (Figure 1). Increasing concentration of $\mathrm{rS100P}$ in the presence of tPA resulted in reduction in the lag period and increasing rates of plasminogen activation for up to at least $3.5 \mu \mathrm{M} \mathrm{rS100P}$ (Figure 1A). Mutant rS100P proteins, $\Delta \mathrm{K} 95$ (Figure 1B) or K95A (Figure 1C) were also tested in the multiwell plasminogen activation assay. To aid comparison between the various recombinant proteins, the optical density readings were replotted against time ${ }^{2}$ and the resulting linear gradients over the first $30 \mathrm{~min}$ of incubation were determined. Removal, or replacement, of the $C$-terminal lysine markedly reduced the ability of rS100P to activate tPA (Figure 1D), demonstrating that $\mathrm{S} 100 \mathrm{P}$ and its $C$-terminal lysine are required for activation of $\mathrm{PAA}$.

\section{Effect of calcium ions on plasminogen activation}

Although S100P binds calcium [23] and has been reported to bind magnesium and zinc ions [24], S100P is unlikely to bind zinc or magnesium ions at their free intracellular or extracellular concentrations [25-27]. Thus, the dependence on only calcium concentration of tPA activation by S100P was determined (Figure 2A). There were statistically significant differences between calcium concentrations, as determined by one-way ANOVA $(\mathrm{F}(8,9)=15.0, \mathrm{P}=0.0002)$. Whilst plasminogen was activated in the presence of $1 \mu \mathrm{M} \mathrm{rS100P}$ and excess tPA, the rate of activation was significantly increased by the presence of $10 \mu \mathrm{M} \mathrm{Ca}^{++}$(95\% CI $=-0.00005$ to $-0.000018, \mathrm{P}=0.001$, Bonferroni correction), but there was no further significant increase at higher calcium ion concentrations up to $10 \mathrm{mM}$ (Figure $2 \mathrm{~A}, 95 \% \mathrm{CI}=-0.000025$ to $0.000007, \mathrm{P}>0.23$, Bonferroni correction). In the absence of $\mathrm{rS} 100 \mathrm{P}$ and in the presence of excess $(5 \mathrm{mM})$ calcium ions, the rate of plasminogen activation was not significantly different from that with no calcium ( $95 \% \mathrm{CI}=-0.000007$ to $0.000025, \mathrm{P}=0.25$, Bonferroni correction), suggesting that the increase in plasminogen activator activity in the presence of calcium ions was due to an effect on the rS100P protein by calcium ions. In contrast, $1 \mu \mathrm{M}$ bovine serum albumin (BSA), in the presence of calcium ions, did not significantly change the initial rate of plasminogen activation by tPA (Figure 2B) $(95 \% \mathrm{CI}=-0.000011$ to $0.000024, \mathrm{P}=0.32$, Bonferroni correction), under conditions when there was a significant activation by $1 \mu \mathrm{M} \mathrm{rS} 100 \mathrm{P}(95 \% \mathrm{CI}=-0.000076$ to $-0.000041, \mathrm{P}=0.002$, Bonferroni correction), showing that the activation observed with $\mathrm{rS100P}$ is not a general property of lysine-containing proteins (Figure 2B). Size Exclusion Chromatography-Multi Angle Light 
Scattering experiments indicated that $>96 \%$ of wild type and mutant S100P proteins were in the dimeric form at calcium concentrations of both 50 and $500 \mu \mathrm{M}$ (Supplementary information 3).

\section{Effect of concentration of rS100P and its mutants on tPA-dependent activation of plasminogen}

Increasing concentrations of $\mathrm{rS} 100 \mathrm{P}$ up to $100 \mathrm{nM}$ in the presence of $5 \mathrm{mM}$ calcium ions resulted in a significantly increased initial rate of tPA-dependent plasminogen activation in vitro (one-way ANOVA $(\mathrm{F}(6,7)=24.4, \mathrm{P}=0.0002)$. Based on the initial gradients of plots of optical density vs time ${ }^{2}$, this effect started to plateau at concentrations of rS100P above $100 \mathrm{nM}$ (Figure 2C). Significant detectable enhancement of the initial rate of plasminogen activation by excess tPA occurred between 50 and $100 \mathrm{nM}(600-1200 \mathrm{ng} / \mathrm{mL}) \mathrm{rS} 100 \mathrm{P}(50$ $\mathrm{nM}, 95 \% \mathrm{CI}-0.000031$ to $0.000003, \mathrm{P}=0.09 ; 100 \mathrm{nM}, 95 \% \mathrm{CI}=-0.000055$ to -0.000021 , $\mathrm{P}=0.0012$, Bonferroni correction) (Figure 2C).

There were significant differences between the ability of wild type and mutant S100P proteins to activate plasminogen activators (one-way ANOVA $(\mathrm{F}(4,10)=194.6, \mathrm{P}<$ 0.0001). Initial rates of plasminogen activation with $1 \mu \mathrm{M} \mathrm{K} 95 \mathrm{~A}$-mutant or $\Delta \mathrm{K} 95$-mutant rS100P were significantly lower than with wild type rS100P (95\% CI, K95A-mutant, 0.000031 to 0.000039 and $\Delta \mathrm{K} 95$-mutant, 0.000028 to 0.000036 , both $\mathrm{P}<0.0001$, Bonferroni correction) (Figure 2D), but both still exhibited residual activation of tPA that was significantly higher than the no-S100P control $(95 \% \mathrm{CI},-0.00001$ to $-0.000003, \mathrm{P}=$ 0.004 and $95 \% \mathrm{CI},-0.000013$ to $-0.000005, \mathrm{P}=0.0003$, respectively, Bonferroni correction), whereas, in the same experiment, $1 \mu \mathrm{M}$ BSA was not significantly different from the no-protein control ( $95 \% \mathrm{CI},-0.000004$ to $0.000004, \mathrm{P}=0.98$, Bonferroni correction) (Figure 2D). The results show that the $C$-terminal lysine is largely required for the ability of S100P to enhance the activity of tPA. This enhancement might be due to interaction of the $C$-terminal lysines with lysine-binding Kringle domains of tPA and/or plasminogen.

\section{Interaction between S100P, plasminogen and plasminogen activators in vitro} The binding of S100P to human plasminogen and tPA was measured using SPR as described in Materials and Methods. Wild type rS100P bound to immobilised human Glu-plasminogen (Figure 3A) with a $K_{\mathrm{d}}$ of $0.12 \mu \mathrm{M}$ (Supplementary information 4), a value that shows a greater affinity between Glu-plasminogen and S100P than between Glu-plasminogen and free lysine residues ( $43 \mu \mathrm{M}$; [39]). Wild type rS100P bound to tPA with a $K_{\mathrm{d}}$ of $1.9 \mu \mathrm{M}$ (Figure 3B and Supplementary information 4 ). In the presence of the lysine analogue, 6-ACA, binding of wild type rS100P to either Glu-plasminogen (Figure $3 \mathrm{~A}$ ) or to tPA (Figure 3B) was markedly reduced, displaying $K_{\mathrm{d}}$ values of 84.0 $\mu \mathrm{M}$ and $74.6 \mu \mathrm{M}$, respectively, confirming the involvement of lysine residues in the interaction of S100P with both plasminogen and tPA.

Calcium chelation with EGTA resulted in only an approximately $50 \%$ decrease in binding of wild type rS100P to Glu-plasminogen (Figure 3A), but completely abolished binding to tPA (Figure 3B), suggesting that activation of S100P by calcium is essential for interaction with tPA, but not for interaction with Glu-plasminogen. In contrast, the loss of the C-terminal lysine virtually abolished the interaction of S100P with Gluplasminogen (Figure 3A), but only partially reduced the extent of interaction of S100P with tPA (Figure 3B). 
Although $1 \mu \mathrm{M}$ wild type rS100P enhanced tPA-dependent plasminogen activation in the multiwell assay, the same concentration of S100P had no effect on urokinase (uPA)dependent plasminogen activation in the multiwell plasminogen activation assays, in the range zero to $50 \mathrm{nM}$ uPA. Whilst the initial rate of plasminogen activation increased with increasing $\mathrm{UPA}$, there was no significant change in activity by $1 \mu \mathrm{M}$ wild type $\mathrm{rS100P}$ at uPA concentrations of 1,5 and $50 \mathrm{nM}(\mathrm{P}=0.216,0.089,0.5$ and 0.273 , respectively), with $\mathrm{S} 100 \mathrm{P}$ just significantly reducing activity at 10 and $25 \mathrm{nM}$ (both, $\mathrm{P}=$ 0.05 , Student's t test) (Figure 3C). In SPR experiments, wild type rS100P bound very poorly to uPA (Fig. 3C) and the bound protein dissociated only slowly from the uPA surface, in the time-frame of the experiment. This poor uPA-rS100P interaction likely accounts for the lack of rS100P-enhanced activation of plasminogen by uPA, whilst the very slow dissociation of rS100P from uPA might account for the reduction of uPAinduced plasminogen activation in the presence of $\mathrm{rS} 100 \mathrm{P}$, as the build up of 'inactive' rS100P-uPA complexes could inhibit further interaction with plasminogen. Thus, rS100P does not activate uPA, but acts specifically on tPA.

\section{Cells expressing non-mutant S100P exhibit enhanced tPA-dependent plasminogen activation}

Following the demonstration of plasminogen activation by S100P protein in vitro, experiments were conducted to find out whether cells expressing S100P exhibited enhanced plasminogen activation, compared to non-expressing cells. Plasminogen activation assays were carried out using cells growing in culture wells, as described in Materials and Methods. PBS was found to be a satisfactory replacement for the Tris buffer system used in the plasminogen activation assays in vitro (Supplementary information 5).

In order to compare the results of multiple experiments, the initial rates of colour development for the various cell lines in each experiment were expressed as a fraction of the result with cells expressing wild type S100P. Figure 4 shows the results of six separate experiments. In each case, cells not expressing S100P, or cells expressing the $\Delta \mathrm{K} 95$ or K95A mutant S100P proteins exhibited reduced ability to activate Gluplasminogen in the presence of added tPA, compared to cells expressing wild type S100P (Figures 4A, results summarised in Figure 4B). As further confirmation of the link between the production of S100P and the enhancement of tPA-catalysed plasminogen activation in cultured cells, an existing S100P inducible system was employed [30]. Induction of S100P with doxycycline for $24 \mathrm{~h} \mathrm{[30]} \mathrm{increased} \mathrm{the} \mathrm{ability}$ of the cells to activate plasminogen in the presence of tPA by $21.3 \%(\mathrm{P}=0.029$, Student's t test; Figure 4C).

\section{Detection of S100P on the outside of S100P-expressing cells}

In order to understand the ability of S100P-expressing cells to activate extracellularlyadded tPA, a quantitative enzyme-linked immunosorbent assay (ELISA) was used to detect S100P directly on the surface of living cells by adding an S100P polyclonal antibody directly to the cell culture medium or after fixation or permeabilisation (one-way ANOVA, $(\mathrm{F}(5,12)=10.9), \mathrm{P}=0.0004) . \mathrm{S} 100 \mathrm{P}$ antibody binding was detected at a significant $(95 \%$ CI, -0.15 to $-0.04, \mathrm{P}=0.0027$, Bonferroni correction), 5.4-fold greater level in living unfixed cells expressing S100P, than from the cell line transfected with empty expression vector (Figure 5A, antibody in medium). A significantly higher level of S100P was detected also when the cells were fixed with formaldehyde (95\% CI, -0.11 to -0.00062 , P $=0.05$, Bonferroni correction), which was not significantly different from the level found when antibody was added directly to the medium ( $95 \% \mathrm{CI},-0.088$ to $0.022, \mathrm{P}=0.22$, 
Bonferroni correction). Upon permeabilisation, a significantly higher optical density was evident with S100P-expressing cells compared to antibody added to the medium $(95 \% \mathrm{CI}$, 0.0017 to $0.112, \mathrm{P}=0.04$, Bonferroni correction), possibly due to some of the intracellular S100P becoming available to the antibody. In order to check that the antibody added to the medium was not reacting with intracellular S100P as a result of cell leakiness, an antibody to the soluble intracellular protein, eEF1A [40] was tested (eEF1A, $(\mathrm{F}(5,12)=211.6), \mathrm{P}=$ $<0.0001)$. In the ELISA assay, there was virtually no detectable binding of the eEF1A antibody when it was added to the medium in either S100P-expressing or control cells (Figure 5B). However, after permeabilisation, there was a significant 134-fold increase in detectable eEF1A antibody binding in both S100P negative control cells $(95 \% \mathrm{CI},-0.94$ to $-0.74, \mathrm{P}<0.0001)$ and in $\mathrm{S} 100 \mathrm{P}$-expressing cells $(95 \% \mathrm{CI}=-1.21$ to $-1.02, \mathrm{P}<0.0001)$ (Figure 5B), suggesting that under the conditions of the ELISA assay, the unfixed cells are intact and not leaking intracellular proteins, thus part of the detected $\mathrm{S} 100 \mathrm{P}$ is displayed to the outside of the cells.

\section{Cell invasion by cells expressing S100P or its mutants}

Cells expressing wild type S100P exhibited a significant 9.4-fold (Figure 6A; 95\% CI, 330.5 to $357.5, \mathrm{P}=<0.0001$, Bonferroni correction) or 8.7-fold (Figure 6B; 95\% CI, -162.9 to $-99.7, \mathrm{P}=<0.0001$, Bonferroni correction) increase in invasion through Matrigel in independent transwell invasion assays, when compared to S100P-negative, vectortransfected control cells. Such an increase was evident in both a clone and a pool of S100P-expressing transfected cells when compared to vector transfected or parental, untransfected, Rama 37 cells (Supplementary information 6).

In contrast, cells expressing the $\mathrm{K} 95 \mathrm{~A}$ or $\Delta 95 \mathrm{~K} C$-terminal mutants of $\mathrm{S} 100 \mathrm{P}$ protein exhibited levels of invasion that were highly significantly lower than with wild type S100P (K95A mutant: Figure 7A, 95\% CI, 316.9 to $343.8, \mathrm{P}<0.0001$; Figure 7B, 95\% CI, 83.1 to 146.3, $\mathrm{P}<0.0001 ; \Delta 95 \mathrm{~K}$ mutant: Figure $6 \mathrm{~A}, 95 \% \mathrm{CI}, 347.9$ to $374.8, \mathrm{P}<0.0001$; Figure $6 \mathrm{~B}, 95 \% \mathrm{CI}=98.742469$ to $161.924197, \mathrm{P}<0.0001$ ) and not significantly different or significantly less than S100P-negative, vector-transfected control cells in two independent experiments (K95A mutant: Figure 6A, 95\% CI, 0.18 to $27.15, \mathrm{P}=0.05$; Figure 6B, 95\% $\mathrm{CI}=-48.3$ to $14.9, \mathrm{P}=0.29$ and $\Delta 95 \mathrm{~K}$ mutant: Figure $6 \mathrm{~A}, 95 \% \mathrm{CI}=-30.8$ to $-3.9, \mathrm{P}=$ 0.014; Figure $6 \mathrm{~B}, \mathrm{CI}=-32.6$ to $30.6, \mathrm{P}=0.95$ ). Thus, altering or deleting the $\mathrm{C}$-terminal lysine of S100P, which we have shown to be important for interacting with tPA and plasminogen, reduces its ability to enhance invasion of the Rama 37 cells.

The effect of 6-aminocaproic acid on S100P dependent cell invasion

To confirm the possible role of S100P lysine residues in the observed changes in cell invasion, $10 \mathrm{mM}$ 6-amino caproic acid had no significant effect on S100P-negative vector control cells $(95 \% \mathrm{CI}=-20.1$ to $6.8, \mathrm{P}=0.32)$, but significantly reduced by $32 \%$ the number of S100P positive cells invading through Matrigel (Figure $6 \mathrm{~A}, 95 \% \mathrm{CI}=110.5$ to 137.5, $\mathrm{P}<0.0001)$. However, the invasion was still significantly higher than for S100P negative control cells $(95 \% \mathrm{CI}=199.9$ to $226.8, \mathrm{P}<0.0001)$. Invasion was also still significantly higher than with cells expressing the $C$-terminal mutants of S100P (K95A, $95 \% \mathrm{CI}=192.9$ to $219.8, \mathrm{P}<0.0001 ; \Delta \mathrm{K} 95,95 \% \mathrm{CI}=223.9$ to $250.8, \mathrm{P}<0.0001)$. This result indicates that lysine residues contribute significantly to S100P induced invasion, but that the dramatic reductions in invasion seen with the $C$-terminal lysine mutant proteins is not entirely due to the absence of the $C$-terminal lysine. 
The effect of S100P antibody added to the culture medium on S100P-dependent invasion

In invasion assays, addition of the $\mathrm{S} 100 \mathrm{P}$ antibody to the medium surrounding wild type S100P-expressing cells (Figure 6B) reduced their invasion by a highly significant $57 \%$ from that of untreated cells (95\% CI, 52.4 to $115.6, \mathrm{P}=<0.0001)$, whereas non-immune goat serum added to the S100P-expressing cells had no significant effect (Figure 6C; 95\% CI, -46.8 to $99.5, \mathrm{P}=0.43$ ). Cells expressing K95A or $\Delta \mathrm{K} 95$ mutant $\mathrm{S} 100 \mathrm{P}$ proteins, or expressing no S100P, showed no significant reduction in invasion upon treatment with the antibody (Figure $6 \mathrm{~B} ; \mathrm{K} 95 \mathrm{~A}, 95 \% \mathrm{CI},-47.3$ to $15.9, \mathrm{P}=0.32 ; \Delta \mathrm{K} 95$, $95 \% \mathrm{CI},-36.9$ to $26.2, \mathrm{P}=0.73$; vector control, $95 \% \mathrm{CI},-47.3$ to $15.9, \mathrm{P}=0.32)$. As it is unlikely that the $\mathrm{S} 100 \mathrm{P}$ antibody can pass into the cells, these results suggest that the stimulatory effect of S100P on invasion depends upon wild-type S100P being accessible from outside the cell and this is not evident with cells expressing S100P protein lacking the $C$-terminal lysine, S100P negative cells nor with non-immune serum.

The effect of protease inhibitors on the rate of S100P-dependent invasion

In order to find out whether the generation of plasmin was associated with the lysineassociated invasive behaviour of the cells, the effects of protease inhibitors on cell invasion were tested. Aprotinin, an inhibitor of serine proteases, plasmin, trypsin, chymotrypsin, kallikrein and activated protein C [41] and $\alpha$-2-antiplasmin, which targets predominantly neutrophil elastase and plasmin [42], were used.

There were significant reductions in invasive activity of 55\% (Figure 6A; 95\% CI, 199.5 to $226.5, \mathrm{P}<0.0001$ ) and $70 \%$ (Figure $6 \mathrm{~B} ; 95 \% \mathrm{CI}, 71.7$ to $134.9, \mathrm{P}<0.0001$ ) when S100P expressing cells were treated with $25 \mu \mathrm{g} / \mathrm{mL}$ aprotinin or $10 \mu \mathrm{g} / \mathrm{mL} \alpha-2$ antiplasmin, respectively. There was no significant reduction in the invasion of control S100P-negative cells by either aprotinin (Figure 6A; 95\% CI, -5.5 to $21.5, \mathrm{P}=0.24$ ) or $\alpha$-2-antiplasmin (Figure 6B; 95\% CI, -31.9 to $31.3, \mathrm{P}=0.98$ ). Whereas $\alpha-2$ antiplasmin did not significantly reduce the invasive potential of cells expressing the mutant S100P proteins (Figure 6B; K95A, 95\% CI, -39.3 to 23.9, $\mathrm{P}=0.62 ; \Delta \mathrm{K} 95,95 \%$ $\mathrm{CI},-37.3$ to $25.9, \mathrm{P}=0.72$ ), aprotinin reduced the invasive potential of cells expressing the K95A mutant protein (Figure 6A; K95A, 95\% CI, 16.9 to 43.8, $\mathrm{P}<0.0001$ ), but not significantly for the $\Delta \mathrm{K} 95$ mutant $(95 \% \mathrm{CI},-17.5$ to $9.5, \mathrm{P}=0.55)$. These results demonstrate that the stimulatory effect of S100P on invasion involves the plasmin/plasminogen pathways, as these specific protease inhibitors significantly disrupted cell invasion.

\section{Discussion}

It has been shown here for the first time that soluble rS100P protein can activate tPA in vitro. The 7.6-fold activation over that with tPA alone is comparable with that of $\sim 9$ fold for S100A4 [18], but less than the 46-fold activation reported for S100A10 [43]. Deleting the $C$-terminal lysine of S100P $(\Delta 95 \mathrm{~K}$, exposing a $C$-terminal leucine) or changing it to alanine (K95A), with no change in the dimeric state of the rS100P, reduced the rates of activation of tPA to only $16 \%$ and $22 \%$, respectively, of the nonmutant S100P protein, similar to the $15 \%$ of activity remaining upon deletion of the two $C$-terminal lysines of S100A10 [43], reflecting the involvement of non- $C$-terminal lysine side chains [21]. 
Direct interaction in vitro between non-mutant S100P and Glu-plasminogen or tPA, individually, has been demonstrated, with $K_{\mathrm{d}}$ values $(0.12 \mu \mathrm{M}$ and $1.9 \mu \mathrm{M}$, respectively) similar to those for S100A10 binding to Glu-plasminogen $(0.66 \mu \mathrm{M}$, calculated in the present experiments (not shown) and $1.81 \mu \mathrm{M}$ reported previously [19]) and to tPA of $0.45 \mu \mathrm{M}$ [19]. However, for S100P, there were differences between the interactions of S100P with Glu-plasminogen and tPA. Whereas the interaction of S100P with tPA required the presence of calcium ions, S100P still bound to Gluplasminogen in the absence of calcium. In contrast, the $C$-terminal lysine mutants of S100P did not bind to Glu-plasminogen, but did bind to tPA, a result which contrasts with that obtained with S100A10 [19]. Thus, the observed dependence of rS100Pmediated plasminogen activation on both the presence of calcium ions and the presence of the $C$-terminal lysine residue, is explained by the former requirement for binding of $\mathrm{S} 100 \mathrm{P}$ to $\mathrm{tPA}$ and the latter requirement for binding to Glu-plasminogen.

In the present multiwell experiments, significant activation of plasminogen activator was detectable with only $50-100 \mathrm{nM} \mathrm{rS100P}(<1 \mu \mathrm{g} / \mathrm{mL})$. S100P has been reported to be present in the extracellular environment $[44,45]$, but at presently unknown concentration. However, the observation that cells constitutively-expressing either of the mutants exhibited reduced plasminogen activation rates compared to those

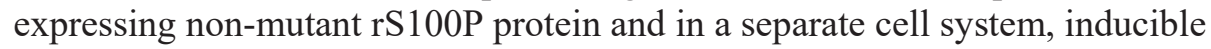
upregulation of S100P enhanced plasminogen activation, shows for the first time that cell-produced S100P can modulate plasminogen activation.

The main findings in this paper are that for the first time, the activation of tPA by an S100 protein in a tumour setting is linked to cell invasion. Elevated levels of tPA have been associated with tumour-associated cell activities in pancreatic cancer cells, but these were not linked specifically to an increase in plasmin activity [46].

In the present experiments, plasmin activity, and thus plasminogen activation, has been directly and specifically linked to S100P-directed cell invasion by the use of inhibitors of plasmin activity, aprotinin or $\alpha$-2-antiplasmin. The specificity of $\alpha$-2-antiplasmin for plasmin [42] has been used previously to show the involvement of plasmin and TPA in chemotactic migration of human T cells [47]. Aprotinin and $\alpha$-2-antiplasmin, individually, significantly inhibited S100P-promoted invasion, but the inhibitors had no effect on invasion by S100P-negative cells, and $\alpha$-2-antiplasmin had no inhibitory effect on cells expressing the K95A or $\Delta \mathrm{K} 95$ mutant $\mathrm{S} 100 \mathrm{P}$ proteins. These results show a direct involvement of plasmin activation in S100P-driven cell invasion. Enhancement of cell invasion by plasmin proteolytic activity is well established in normal tissue [48] and tumours $[49,50]$.

Given the link between plasmin activation and cell invasion in S100P expressing cells, the activation of tPA, demonstrated in vitro and in cultured cells, might contribute to the previously-reported metastasis inducing properties of S100P [7]. Neither the S100Pexpressing cells, nor the control cells, exhibited detectable plasminogen mRNA by PCR (Supplementary information 7), however, the average blood concentration of plasminogen $(1.33 \mu \mathrm{M}$; [51]) is much greater than both the Glu-plasminogen concentration used in the in vitro assays $(100 \mathrm{nM})$ and the experimentally-determined $K_{\mathrm{d}}$ values for the S100P:Glu-plasminogen interaction $(0.12 \mu \mathrm{M})$; thus, at suitable S100P concentrations in vivo, S100P:plasminogen interaction could take place during the 
metastatic process. However, in contrast, the average blood concentration of tPA of only $0.143 \mathrm{nM}$ [51] is much lower than both the concentration of tPA used in the in vitro multiwell assay, in order to detect suitably large optical density changes, and the measured $K_{\mathrm{d}}$ for the interaction between S100P and tPA $(1.9 \mu \mathrm{M})$. However, the Rama 37 cells do produce PCR-detectable tPA mRNA (Supplementary information 7), which, if translated into active tPA protein, could locally raise the tPA concentration in the surrounding medium.

S100P has been detected on the cell surface from outside the cell using an antibody (Figure 5), which also reduced the cell invasion (Figure 6). Thus, on the cell surface, S100P might be complexed with other cell components. S100A10, a major tPA activator, exhibits a 340-fold increase in tPA activation when it is associated with its natural cell surface receptor, annexin AII [52]. The cells used in the present experiments exhibit abundant levels of annexin AII mRNA and protein by PCR (not shown) and Western blot (Supplementary information 8), respectively. However, so far, it has not been possible to show, experimentally in vitro, a physical interaction between S100P and commercially available recombinant annexin AII protein under conditions in which S100A10 $\left(K_{\mathrm{d}}=3.7 \pm 1.1 \times 10^{-8} \mathrm{M}\right)$ and S100A4 $\left(K_{\mathrm{d}}=3.45 \pm 1.7 \times 10^{-6} \mathrm{M}\right)$ bind to immobilised annexin AII (Sourav, V. and Barraclough, R, unpublished observation). In other systems, S100P interacts/colocalises in surface protrusions with the cytoskeletal protein ezrin [28, 53] and interacts with the adaptor protein, IQGAP1 [29]. Both these proteins localise to the cortical cytoskeleton in contact with the cell membrane [54]. Elsewhere, extracellular S100P, has been reported to interact with the RAGE receptor [45]. Based on the assumption that binding of S100P to these proteins would allow contact of the S100P C-terminal lysine with tPA, these various proteins might provide a means for displaying S100P on the outside of the cell and thereby enhance its ability to activate plasminogen activator.

\section{Figure legends}

Figure 1. S100P enhances the rate of plasminogen activation by tissue plasminogen activator in a cell-free multiwell assay

(A), a multiwell colorimetric assay for the generation of plasmin from Glu-plasminogen was carried out as described in Materials and Methods in a buffer consisting of $50 \mathrm{mM}$ Tris- $\mathrm{HCl}, \mathrm{pH} 7.4,100 \mathrm{mM} \mathrm{NaCl}$ and $5 \mathrm{mM} \mathrm{CaCl}_{2}$ either without (curve 1) or with t-PA and 0 (curve 2), 0.24 (curve 3), 0.48 (curve 4), 0.72 (curve 5), 2.4 (curve 6) or 3.4

(curve 7) $\mu \mathrm{M} \mathrm{rS100P}$ wild type. (B), as (A), but with a rS100P mutant protein, $\Delta \mathrm{K} 95$, in which the C-terminal lysine had been deleted. (C), as (A), but with a rS100P mutant protein, K95A, in which the $\mathrm{C}$-terminal lysine had been replaced with alanine. The accumulation of plasmin from Glu-plasminogen was monitored colorimetrically at 405 $\mathrm{nm}$ at 5-min intervals up to $120 \mathrm{~min}$. (D), initial gradients of plots of optical density vs time $(\mathrm{min})^{2}$ for wild type $(\bullet)$, deletion mutant, $\Delta \mathrm{K} 95(\mathbf{\Delta})$ and substitution mutant, K95A (ם).

Figure 2. S100P-dependent activation of plasminogen activator in a multiwell assay Plasminogen activation assays were carried out in the presence of excess IPA and the activation of plasminogen was monitored by the appearance of colour arising from the cleavage of a plasmin-specific substrate as described in Materials and Methods. The initial gradients of optical density against time $(\mathrm{min})^{2}$ over the first $30 \mathrm{~min}$ are plotted 
for each experimental treatment. Error bars are the means of two determinations carried out at the same time (A, B and C) or three independent experiments (D). In (A), assays were carried out with $1 \mu \mathrm{M} \mathrm{rS100P}$ and the various concentrations of calcium chloride indicated; in (B), in the presence of $5 \mathrm{mM}$ calcium chloride with no added protein or with $1 \mu \mathrm{M} \mathrm{rS100P}$ or with $1 \mu \mathrm{M}$ bovine serum albumin. In $(\mathbf{C})$, assays were carried out in the presence of $100 \mu \mathrm{M}$ calcium chloride and varying concentrations of $\mathrm{rS100 \textrm {P }}$ shown in the figure. P values (ANOVA with Bonferroni correction) are shown for each concentration relative to the zero rS100P control. In (D), assays were carried out with $100 \mu \mathrm{M}$ calcium chloride and $1 \mu \mathrm{M}$ of wild type rS100P, K95A mutant, $\Delta$ K95 mutant or BSA.

\section{Figure 3. S100P binding to plasminogen, tPA and uPA}

(A and B), ligand surfaces, Glu-plasminogen (A) and tPA (B), were prepared via amine coupling reactions as described in Materials and Methods. Wild type (black lines) and mutant S100P proteins, K95A (red lines), $\Delta \mathrm{K} 95$ (green lines) were injected over the prepared surfaces and binding interactions determined by changes in surface plasmon resonance. Both the running buffer and analyte dilution buffer contained $100 \mu \mathrm{M} \mathrm{CaCl}_{2}$. Wild type S100P protein was also tested with $0.5 \mathrm{mM}$ EGTA (orange lines) and $10 \mathrm{mM}$ 6-ACA (violet lines), which were added to the analyte samples only. Duplicate analyses are shown, except for wild type S100P, which served as a positive control. (C) Lack of effect of S100P on the activation of plasminogen by uPA in a multiwell assay. Plasminogen activation assays were carried out in the presence of increasing concentrations of $\mathrm{UPA}$ and the activation of plasminogen was monitored by the appearance of colour arising from the cleavage of a plasmin-specific substrate as described in Materials and Methods. The initial gradients of optical density against time $(\mathrm{min})^{2}$ over the first $30 \mathrm{~min}$ are plotted for each experimental treatment in the absence (black bars) or presence (white bars) of $1 \mu \mathrm{M} \mathrm{rS100P}$. Error bars are the means of duplicate determinations carried out at the same time. (D) uPA ligand surfaces were prepared via amine coupling reactions, as described in Materials and Methods. Plasminogen (blue line), wild type rS100P (black lines) and mutant rS100P proteins, $\mathrm{K} 95 \mathrm{~A}$ (red lines) or $\Delta \mathrm{K} 95$ (green lines) were injected over the prepared surfaces and binding interactions determined as for the Glu-plasminogen and tPA surfaces. Both the running buffer and analyte dilution buffer contained $100 \mu \mathrm{M} \mathrm{CaCl}_{2}$.

\section{Figure 4. Activation of plasminogen by S100P}

(A-C) S100P positive and parental S100P-negative cell lines were cultured in normal medium and the medium changed to PBS. Glu-plasminogen, tPA and chromogenic substrate were added as described in Materials and Methods and the cells incubated at $37^{\circ} \mathrm{C}$. At 10-min intervals, samples of the medium were taken and the optical density of the coloured product of plasmin activity was measured. The initial gradients of colour development with time were normalised to the initial gradients for wild type S100Pcontaining cells for each of 6 independent experiments (A) using cloned and pooled cell lines with wild type S100P (black columns), S100P $\Delta$ K95 mutant (white columns), S100P K95A mutant (grey columns), S100P-negative empty vector control cell lines/pools (dotted columns) and parental untransfected Rama 37 cells (striped columns). (B) shows the mean and standard deviations of the pooled results from (A). The key to the patterns of the bars is shown for panels $\mathbf{A}$ and $\mathbf{B}$. In (C), a similar experiment was carried out on Rama 37 cells bearing a doxycycline-inducible promoter, before and after induction of S100P. 
Figure 5. ELISA quantitation of S100P and eEF1A antibody binding to the surface of S100P-negative and S100P-positive living cells

Antibodies to S100P (A) or eEF1A (B) were added to the medium surrounding cultured cells and incubated for $1 \mathrm{~h}$ (Antibody in medium), or the cells were fixed with $3.7 \%$ (w/v) paraformaldehyde in PBS prior to adding antibody (Antibody after fixation), or the cells were subjected to permeabilisation with Triton X-100 and fixation with 3.7\% $(\mathrm{w} / \mathrm{v})$ paraformaldehyde in PBS, prior to adding the antibody (Antibody after permeabilisation). The cells were subject to an antibody-detecting ELISA and the optical density of the resulting colour determined, as described in Materials and Methods. White bars, S100P-negative cells, black bars, S100P-positive cells. Error bars are $\pm \mathrm{SD}$ of triplicate determinations in representative experiments. $\mathrm{P}$ values are derived from one-way ANOVA with Bonferroni correction).

Figure 6. The effect of extracellular addition of 6-aminocaproic acid, an S100P antibody, aprotinin or $\alpha$-2-antiplasmin on the rate of invasion through Matrigel by cells expressing wild type and mutant $\mathrm{S100P}$ proteins.

Cell invasion assays were carried out in transwell chambers coated with Matrigel, as described in Materials and Methods. The mean numbers of cells passing through the Matrigel are plotted for cells expressing wild type S100P (Rama $37+$ S100P), K95Amutant of S100P (Rama $37+$ S100P K95A), $\Delta$ K95 mutant of S100P (Rama $37+$ S100P $\Delta$ K95), or cells not expressing S100P (Rama 37 + vector control). Results are expressed as a $\%$ of the invasion of the untreated Rama $37+$ S100P cells. (A) The effect on cell invasion of $10 \mathrm{mM}$ 6-aminocaproic acid (ACA; striped bars) or $25 \mu \mathrm{g} / \mathrm{mL}$ aprotinin (light grey bars) in the extracellular medium. (B) The effect on cell invasion of a five-hundred-fold dilution of a goat S100P antibody (stippled bars) or $10 \mu \mathrm{M} \alpha-2$ antiplasmin (black bars) added to the extracellular medium. (C) The effect of nonimmune goat serum on cell invasion (black bars). White bars in all panels are untreated cells normalised to $100 \%$. Error bars are \pm SD of 3 replicates within a single experiment. $\mathrm{P}$ values (ANOVA with Bonferroni correction) are shown.

\section{Acknowledgements}

We thank Dr Min Du (Institute of Integrative Biology) and Dr Guozheng Wang (Institute of Global Health) for providing the S100P inducible Rama 37 cell line and Dr Caroline Dart (Institute of Integrative Biology) for providing control rat liver cDNA.

\section{Declarations of interest}

The authors have no conflicts of interest to declare.

\section{Author contribution}

$\mathrm{RB}$ conceived and co-ordinated the study and wrote the manuscript. MS carried out pilot experiments and contributed to the manuscript. TMI produced and characterised the S100P and S100P mutant expression systems and developed the cell lines expressing wild type and mutant S100P proteins. SRG carried out all the S100P ELISA assays, contributed text and commented scientifically and extensively on the manuscript. MA-M planned and carried out the invasion assays. All other practical aspects of the project were carried out by $\mathrm{CC}$ who also contributed text for and commented on the manuscript. PSR made available the Rama 37 cell line, contributed scientifically to, and commented on, the manuscript. 
Funding information

The authors would like to thank The Cancer and Polio Research Fund and the James Tudor Foundation for supporting this work through research grants to RB, the Aston University Biomedical Sciences Research Funds for consumables to SRG and the Ministry of Higher Education and Scientific Research, Kufa University, Iraq for a studentship to MA-M.

\section{References}

1 Rudland, P. S., Platt-Higgins, A., Renshaw, C., West, C. R., Winstanley, J. H. R., Robertson, L. and Barraclough, R. (2000) Prognostic significance of the metastasisinducing protein S100A4 (p9Ka) in human breast cancer. Cancer Res. 60, 1595-1603 2 Gongoll, S., Peters, G., Mengel, M., Piso, P., Klempnauer, J., Kreipe, H. and von Wasielewski, R. (2002) Prognostic significance of calcium-binding protein S100A4 in colorectal cancer. Gastroenterology. 123, 1478-1484

3 Andersen, K., Nesland, J. M., Holm, R., Flørenes, V. A., Fodstad, Ø. and Maelandsmo, G. M. (2004) Expression of S100A4 combined with reduced E-cadherin expression predicts patient outcome in malignant melanoma. Mod. Pathol. 17, 990-997

4 Moriyama-Kita, M., Endo, Y., Yonemura, Y., Heizmann, C. W., Schäfer, B. W., Sasaki, T. and Yamamoto, E. (2004) Correlation of S100A4 expression with invasion and metastasis in oral squamous cell carcinoma. Oral Oncol. 40, 496-500

5 Hemandas, A. K., Salto-Tellez, M., Maricar, S. H., Leong, A. F. and Leow, C. K. (2006) Metastasis-associated protein S100A4-a potential prognostic marker for colorectal cancer. J. Surg. Oncol. 93, 498-503

6 Wang, Q., Zhang, Y. N., Lin, G. L., Qiu, H. Z., Wu, B., Wu, H. Y., Zhao, Y., Chen, Y. J. and Lu, C. M. (2012) S100P, a potential novel prognostic marker in colorectal cancer. Oncol Rep. 28, 303-310

7 Wang, G., Platt-Higgins, A., Carroll, J., de Silva Rudland, S., Winstanley, J., Barraclough, R. and Rudland, P. S. (2006) Induction of metastasis by S100P in a rat mammary model and its association with poor survival of breast cancer patients. Cancer Res. 66, 1199-1207

8 Yuan, R. H., Chang, K. T., Chen, Y. L., Hsu, H. C., Lee, P. H., Lai, P. L. and Jeng, Y. M. (2013) S100P expression is a novel prognostic factor in hepatocellular carcinoma and predicts survival in patients with high tumor stage or early recurrent tumors. PLoS One. 8, e65501

9 Davies, M. P., Rudland, P. S., Robertson, L., Parry, E. W., Jolicoeur, P. and Barraclough, R. (1996) Expression of the calcium-binding protein S100A4 (p9Ka) in MMTV-neu transgenic mice induces metastasis of mammary tumours. Oncogene. 13, $1631-1637$

10 Ambartsumian, N., Grigorian, M., Larsen, F., Karlstrom, O., Sidenius, N., Rygaard, J., Georgiev, G. and Lukanidin, E. (1996) Metastasis of mammary carcinomas in GRS/A hybrid mice transgenic for the $m t s 1$ gene. Oncogene. 13, 1621-1630

11 Davies, B. R., Davies, M. P. A., Gibbs, F. E. M., Barraclough, R. and Rudland, P. S. (1993) Induction of the metastatic phenotype by transfection of a benign rat mammary epithelial cell line with the gene for $\mathrm{p} 9 \mathrm{Ka}$, a rat calcium-binding protein but not with the oncogene EJ ras-1. Oncogene. 8, 999-1008

12 Tarabykina, S., Griffiths, T. R., Tulchinsky, E., Mellon, J. K., Bronstein, I. B. and Kriajevska, M. (2007) Metastasis-associated protein S100A4: spotlight on its role in cell migration. Curr. Cancer Drug Targets. 7, 217-228

13 Gross, S. R., Sin, C. G., Barraclough, R. and Rudland, P. S. (2013) Joining S100 proteins and migration: for better or for worse, in sickness and in health. Cell Mol Life Sci. 71, 1551-1579 
14 Kriajevska, M., Cardenas, M., Grigorian, M., Ambartsumian, N., Georgiev, G. and Lukanidin, E. (1994) Non-muscle myosin heavy chain as a possible target for protein encoded by metastasis-related $m t s-1$ gene. J. Biol. Chem. 269, 19679-19682

15 Grigorian, M., Andresen, S., Tulchinsky, E., Kriajevska, M., Carlberg, C., Kruse, C., Cohn, M., Ambartsumian, N., Christensen, A., Selivanova, G. and Lukanidin, E. (2001) Tumor suppressor $\mathrm{p} 53$ protein is a new target for the metastasis-associated Mts1/S100A4 protein: functional consequences of their interaction. J. Biol. Chem. 276, 22699-22708 16 Schmidt-Hansen, B., Ornas, D., Grigorian, M., Klingelhöfer, J., Tulchinsky, E., Lukanidin, E. and Ambartsumian, N. (2004) Extracellular S100A4(mts1) stimulates invasive growth of mouse endothelial cells and modulates MMP-13 matrix metalloproteinase activity. Oncogene. 23, 5487-5495

17 Ambartsumian, N., Klingelhöfer, J., Grigorian, M., Christensen, C., Kriajevska, M., Tulchinsky, E., Georgiev, G., Berezin, V., Bock, E., Rygaard, J., Cao, R., Cao, Y. and Lukanidin, E. (2001) The metastasis-associated Mts1(S100A4) protein could act as an angiogenic factor. Oncogene. 20, 4685-4695.

18 Semov, A., Moreno, M. J., Onichtchenko, A., Abulrob, A., Ball, M., Ekiel, I., Pietrzynski, G., Stanimirovic, D. and Alakhov, V. (2005) Metastasis-associated protein S100A4 induces angiogenesis through interaction with Annexin II and accelerated plasmin formation. J. Biol. Chem. 280, 20833-20841

19 MacLeod, T. J., Kwon, M., Filipenko, N. R. and Waisman, D. M. (2003)

Phospholipid-associated annexin A2-S100A10 heterotetramer and its subunits: characterization of the interaction with tissue plasminogen activator, plasminogen, and plasmin. J Biol Chem. 278, 25577-25584

20 Surette, A. P., Madureira, P. A., Phipps, K. D., Miller, V. A., Svenningsson, P. and Waisman, D. M. (2011) Regulation of fibrinolysis by S100A10 in vivo. Blood. 118, 31723181

21 Miller, V. A., Madureira, P. A., Kamaludin, A. A., Komar, J., Sharma, V., Sahni, G., Thelwell, C., Longstaff, C. and Waisman, D. M. (2017) Mechanism of plasmin generation by S100A10. Thromb Haemost. 117, 1058-1071

22 O'Connell, P. A., Surette, A. P., Liwski, R. S., Svenningsson, P. and Waisman, D. M. (2010) S100A10 regulates plasminogen-dependent macrophage invasion. Blood. 116, $1136-1146$

23 Gribenko, A., Lopez, M. M., Richardson, J. M., 3rd and Makhatadze, G. I. (1998) Cloning, overexpression, purification, and spectroscopic characterization of human S100P. Protein Sci. 7, 211-215

24 Gribenko, A. V. and Makhatadze, G. I. (1998) Oligomerization and divalent ion binding properties of the S100P protein: a Ca2+/Mg2+-switch model. J Mol Biol. 283, 679-694.

25 Frederickson, C. J., Giblin, L. J., Krezel, A., McAdoo, D. J., Mueller, R. N., Zeng, Y., Balaji, R. V., Masalha, R., Thompson, R. B., Fierke, C. A., Sarvey, J. M., de Valdenebro, M., Prough, D. S. and Zornow, M. H. (2006) Concentrations of extracellular free zinc (pZn)e in the central nervous system during simple anesthetization, ischemia and reperfusion. Exp Neurol. 198, 285-293

26 Maret, W. (2015) Analyzing free zinc(II) ion concentrations in cell biology with fluorescent chelating molecules. Metallomics. 7, 202-211

27 Romani, A. M. (2011) Cellular magnesium homeostasis. Arch Biochem Biophys. 512, 1-23

28 Koltzscher, M., Neumann, C., Konig, S. and Gerke, V. (2003) Ca2+-dependent binding and activation of dormant ezrin by dimeric S100P. Mol. Biol. Cell. 14, 2372-2384 
29 Heil, A., Nazmi, A. R., Koltzscher, M., Poeter, M., Austermann, J., Assard, N., Baudier, J., Kaibuchi, K. and Gerke, V. (2011) S100P is a novel interaction partner and regulator of IQGAP1. J Biol Chem. 286, 7227-7238

30 Du, M., Wang, G., Ismail, T. M., Gross, S., Fernig, D. G., Barraclough, R. and Rudland, P. S. (2012) S100P dissociates myosin IIA filaments and focal adhesion sites to reduce cell adhesion and enhance cell migration. J. Biol. Chem. 287, 15330-15344

31 Shen, Z. Y., Fang, Y., Zhen, L., Zhu, X. J., Chen, H., Liu, H., Jiang, B., Li, G. X. and Deng, H. J. (2016) Analysis of the predictive efficiency of S100P on adverse prognosis and the pathogenesis of S100P-mediated invasion and metastasis of colon adenocarcinoma. Cancer Genet. 209, 143-153

32 Dunnington, D. J., Monaghan, P., Hughes, C. M. and Rudland, P. S. (1983) Phenotypic instability of rat mammary tumor epithelial cells. J. Natl. Cancer Inst. 71, $1227-1240$

33 Ismail, T., Fernig, D., Rudland, P., Terry, C., Wang, G. and Barraclough, R. (2008) The basic C-terminal amino acids of calcium-binding protein S100A4 promote metastasis Carcinogenesis. 29, 2259-2266

34 Jenkinson, S. R., Barraclough, R., West, C. R. and Rudland, P. S. (2004) S100A4 regulates cell motility and invasion in an in vitro model for breast cancer metastasis. Br. J. Cancer. 90, 253-262

35 Verderio, E., Gaudry, C., Gross, S., Smith, C., Downes, S. and Griffin, M. (1999) Regulation of cell surface tissue transglutaminase: effects on matrix storage of latent transforming growth factor-beta binding protein-1. J Histochem Cytochem. 47, 1417-1432 36 Patel, P., Clarke, C., Barraclough, D. L., Jowitt, T. A., Rudland, P. S., Barraclough, R. and Lian, L. Y. (2013) Metastasis-promoting anterior gradient 2 protein has a dimeric thioredoxin fold structure and a role in cell adhesion. J Mol Biol. 425, 929-943

37 Chen, H., Fernig, D. G., Rudland, P. S., Sparks, A., Wilkinson, M. C. and Barraclough, R. (2001) Binding to intracellular targets of the metastasis-inducing protein, S100A4 (p9Ka). Biochem Biophys Res Commun. 286, 1212-1217

38 Kwon, M., MacLeod, T. J., Zhang, Y. and Waisman, D. M. (2005) S100A10, annexin A2, and annexin a2 heterotetramer as candidate plasminogen receptors. Front Biosci. 10, 300-325

39 Bok, R. A. and Mangel, W. F. (1985) Quantitative characterization of the binding of plasminogen to intact fibrin clots, lysine-sepharose, and fibrin cleaved by plasmin. Biochemistry. 24, 3279-3286

40 Vera, M., Pani, B., Griffiths, L. A., Muchardt, C., Abbott, C. M., Singer, R. H. and Nudler, E. (2014) The translation elongation factor eEF1A1 couples transcription to translation during heat shock response. Elife. 3, e03164

41 Mahdy, A. M. and Webster, N. R. (2004) Perioperative systemic haemostatic agents. British journal of anaesthesia. 93, 842-858

42 Shieh, B. H. and Travis, J. (1987) The reactive site of human alpha 2-antiplasmin. J Biol Chem. 262, 6055-6059

43 Kassam, G., Le, B. H., Choi, K. S., Kang, H. M., Fitzpatrick, S. L., Louie, P. and Waisman, D. M. (1998) The p11 subunit of the annexin II tetramer plays a key role in the stimulation of t-PA-dependent plasminogen activation. Biochemistry. 37, 16958-16966 $44 \mathrm{Hu}, \mathrm{R}$., Huffman, K. E., Chu, M., Zhang, Y., Minna, J. D. and Yu, Y. (2016) Quantitative secretomic analysis identifies extracellular protein factors that modulate the metastatic phenotype of non-small cell lung cancer. J Proteome Res. 15, 477-486 45 Arumugam, T., Simeone, D. M., Schmidt, A. M. and Logsdon, C. D. (2004) S100P stimulates cell proliferation and survival via receptor for activated glycation end products (RAGE). J Biol Chem. 279, 5059-5065 
46 Diaz, V. M., Planaguma, J., Thomson, T. M., Reventos, J. and Paciucci, R. (2002) Tissue plasminogen activator is required for the growth, invasion, and angiogenesis of pancreatic tumor cells. Gastroenterology. 122, 806-819

47 Lorenz, N., Loef, E. J., Kelch, I. D., Verdon, D. J., Black, M. M., Middleditch, M. J., Greenwood, D. R., Graham, E. S., Brooks, A. E., Dunbar, P. R. and Birch, N. P. (2016) Plasmin and regulators of plasmin activity control the migratory capacity and adhesion of human $\mathrm{T}$ cells and dendritic cells by regulating cleavage of the chemokine CCL21.

Immunol Cell Biol. 94, 955-963

48 Graham, C. H. and Lala, P. K. (1992) Mechanisms of placental invasion of the uterus and their control. Biochem Cell Biol. 70, 867-874

49 Kobayashi, H., Shinohara, H., Takeuchi, K., Itoh, M., Fujie, M., Saitoh, M. and Terao, T. (1994) Inhibition of the soluble and the tumor cell receptor-bound plasmin by urinary trypsin inhibitor and subsequent effects on tumor cell invasion and metastasis.

Cancer Res. 54, 844-849

50 Kramer, M. D., Reinartz, J., Brunner, G. and Schirrmacher, V. (1994) Plasmin in pericellular proteolysis and cellular invasion. Invasion Metastasis. 14, 210-222

51 Leipnitz, G., Miyashita, C., Heiden, M., von Blohn, G., Kohler, M. and Wenzel, E. (1988) Reference values and variability of plasminogen in healthy blood donors and its relation to parameters of the fibrinolytic system. Haemostasis. 18 Suppl 1, 61-68

52 Kassam, G., Choi, K. S., Ghuman, J., Kang, H. M., Fitzpatrick, S. L., Zackson, T., Zackson, S., Toba, M., Shinomiya, A. and Waisman, D. M. (1998) The role of annexin II tetramer in the activation of plasminogen. J Biol Chem. 273, 4790-4799

53 Austermann, J., Nazmi, A. R., Muller-Tidow, C. and Gerke, V. (2008)

Characterization of the $\mathrm{Ca} 2+$-regulated ezrin-S100P interaction and its role in tumor cell migration. J Biol Chem. 283, 29331-29340

54 Nammalwar, R. C., Heil, A. and Gerke, V. (2015) Ezrin interacts with the scaffold protein IQGAP1 and affects its cortical localization. Biochim Biophys Acta. 1853, 20862094 


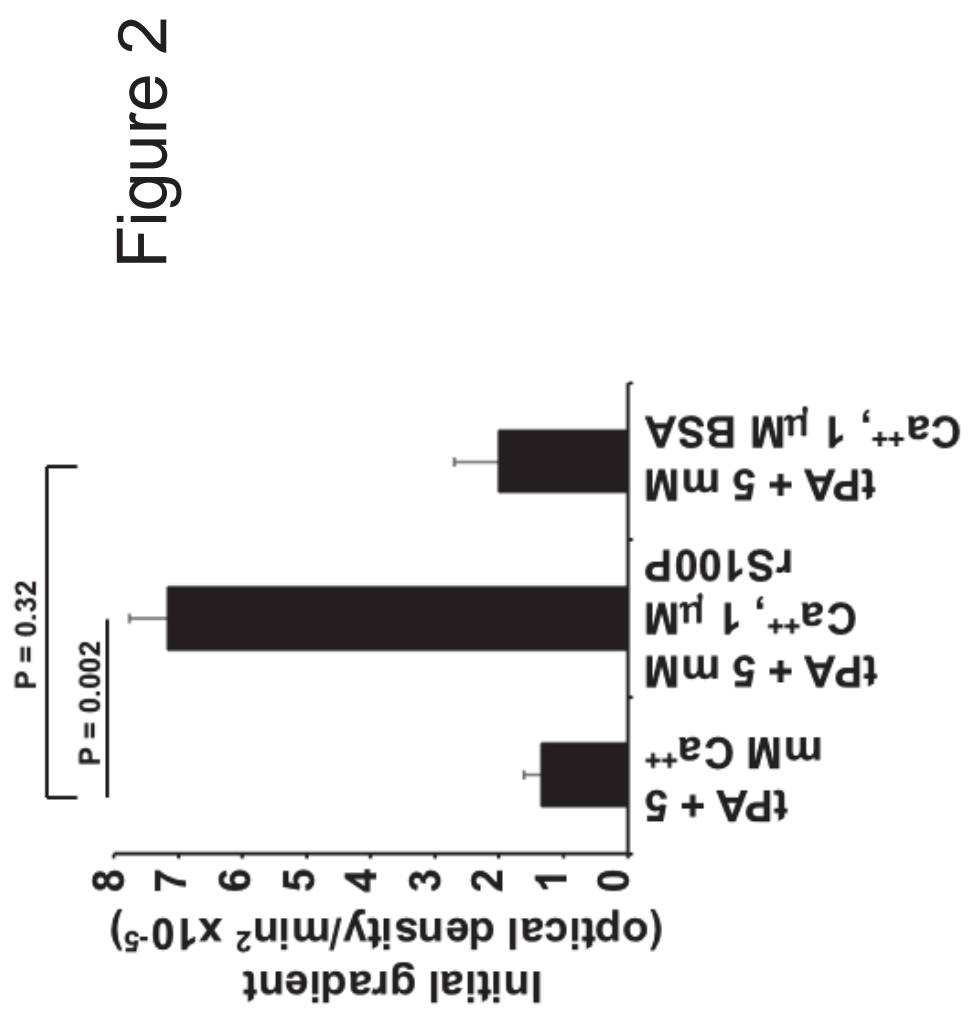

m
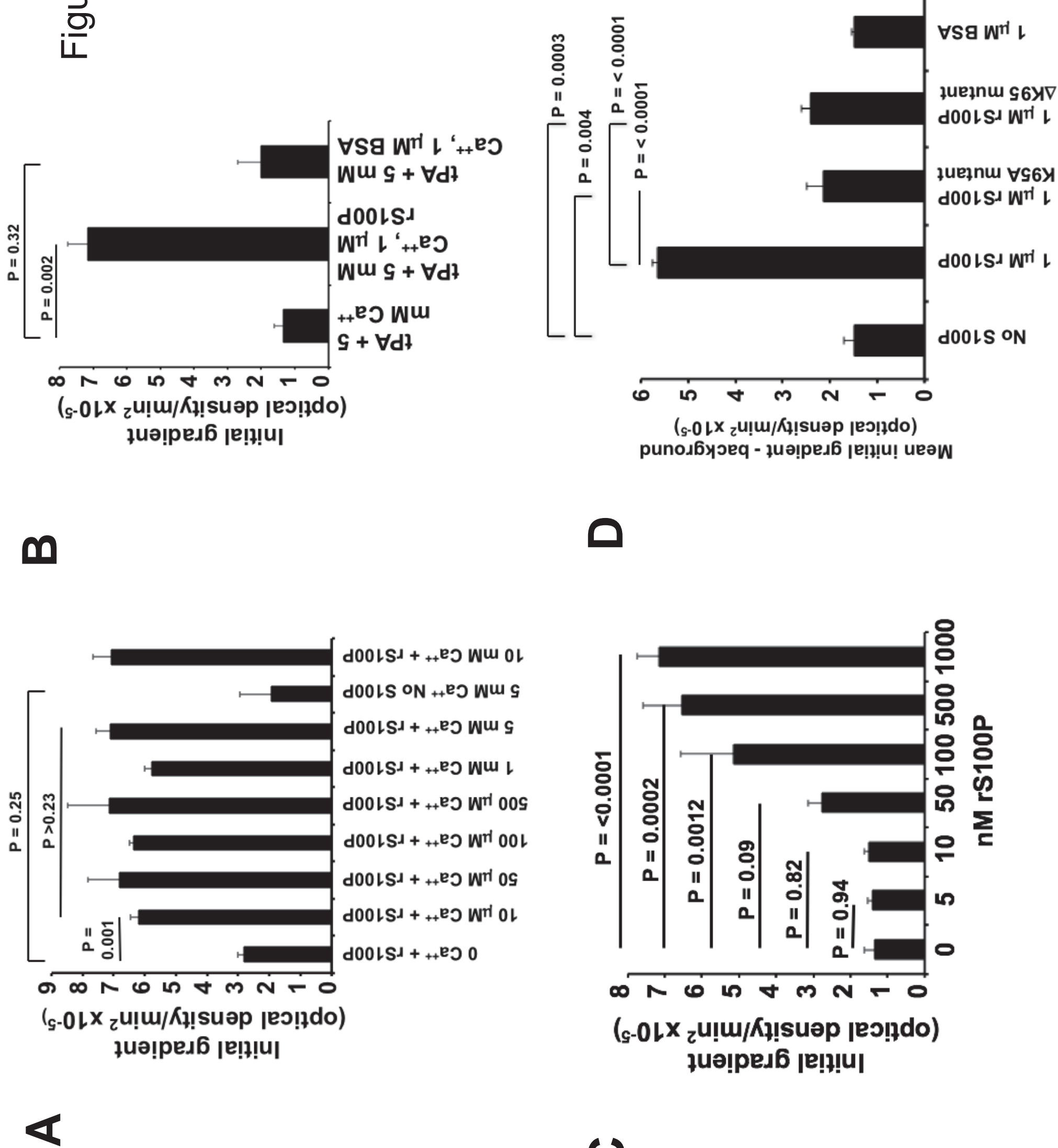


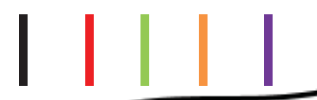

ह

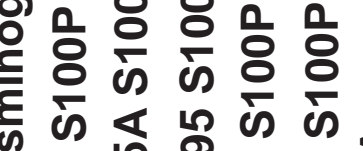

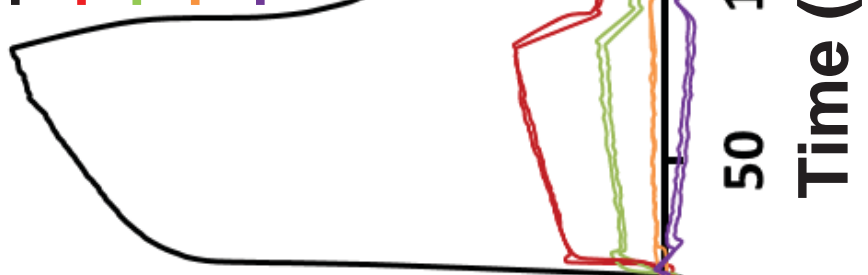

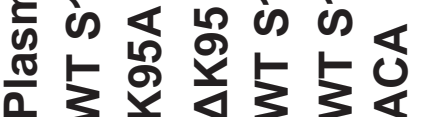
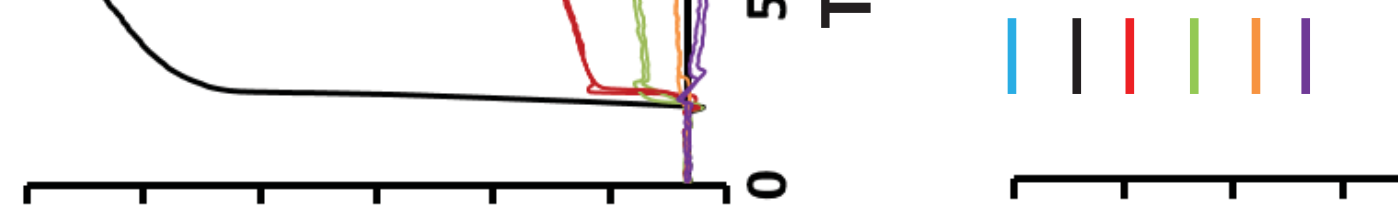

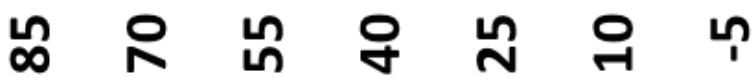

sł!un əsuodsəy

$m$

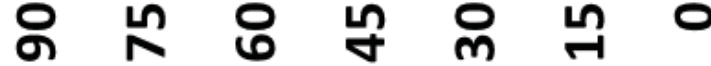

sł!un əsuodsəy

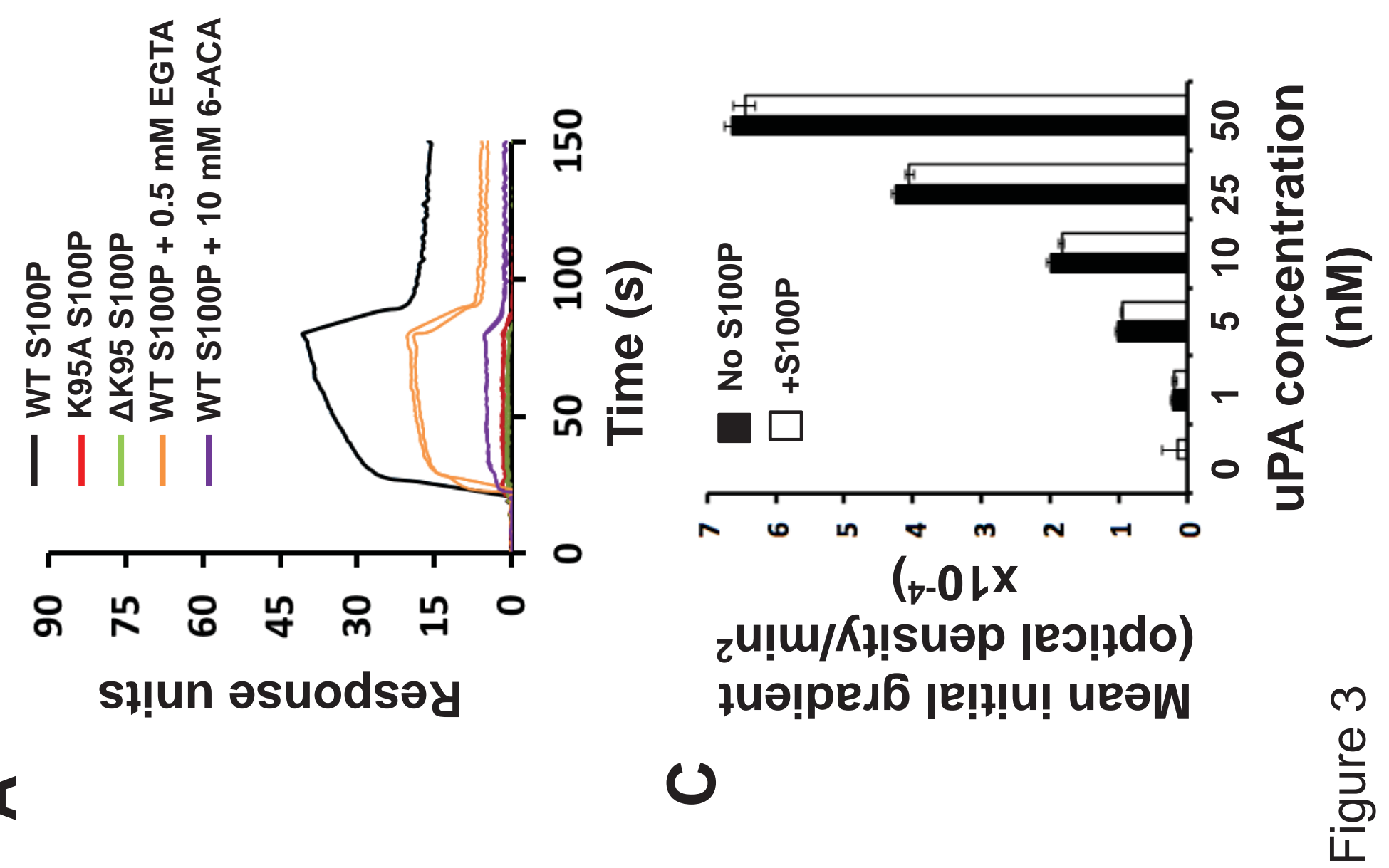




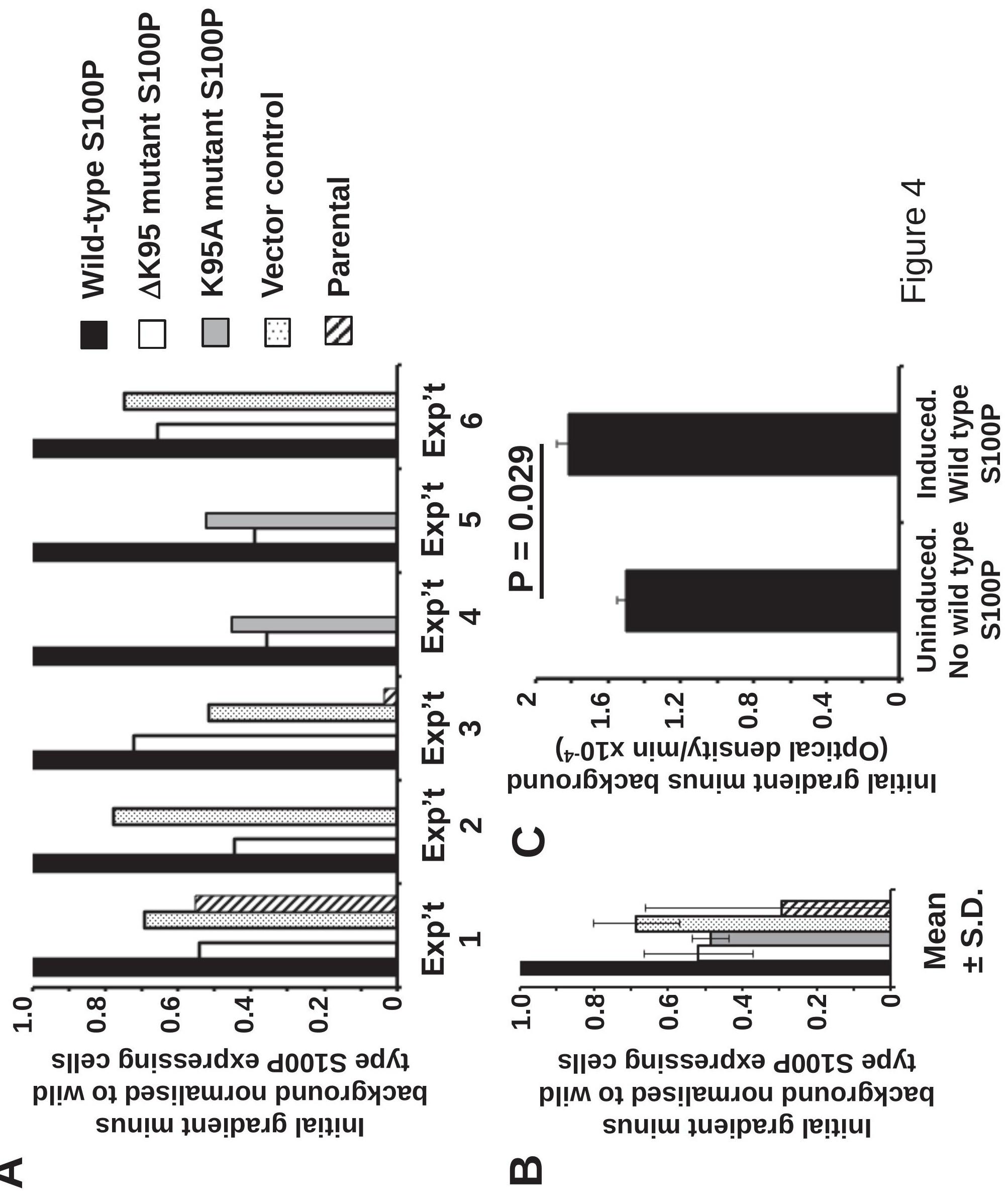


$m$

I0

$\varangle$

인

0

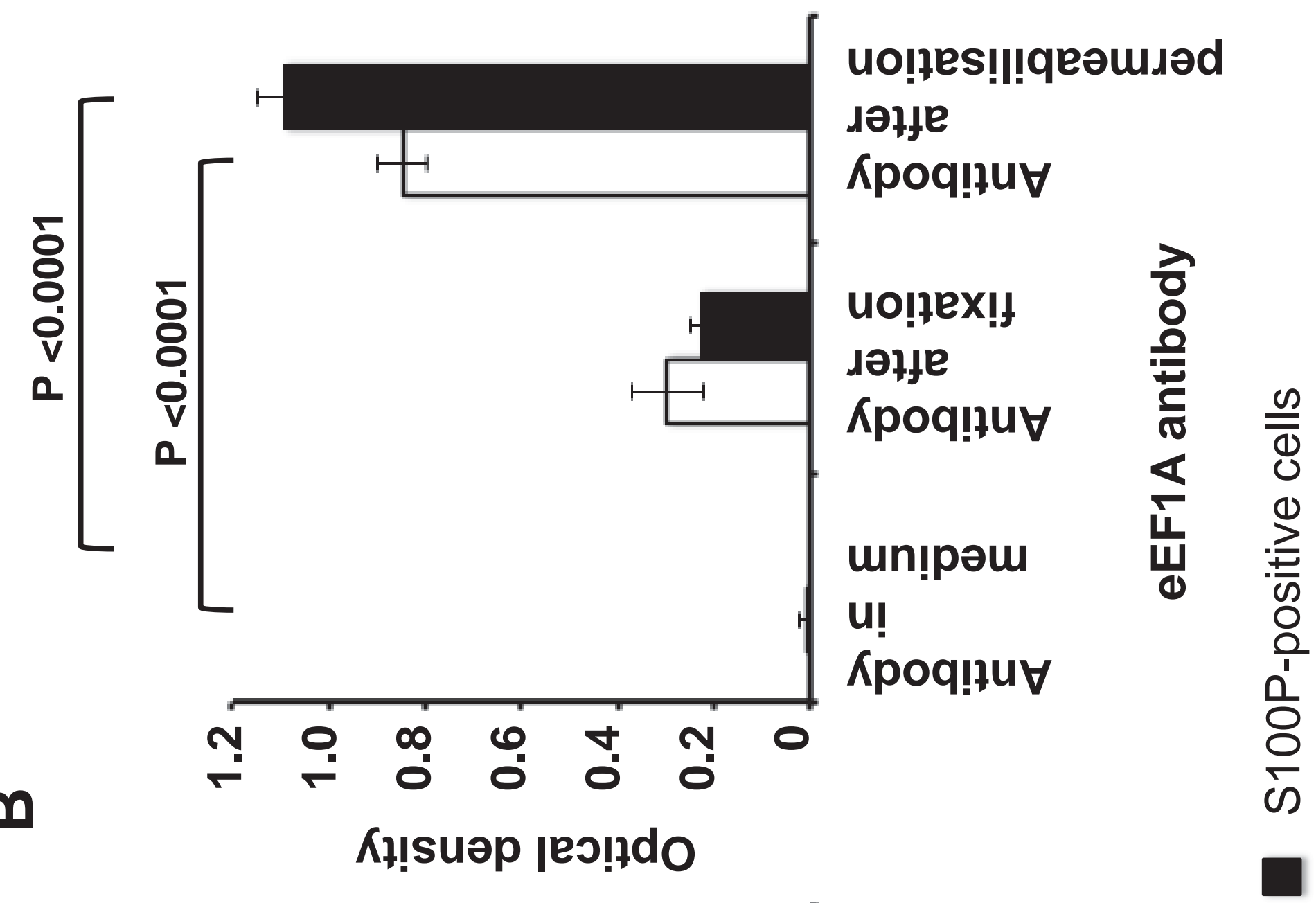

uo!̣es!!!qeəuıәd נәңе

Крoq!qu

uo!fexy

Jәңе

Кpoq!qu $\forall$
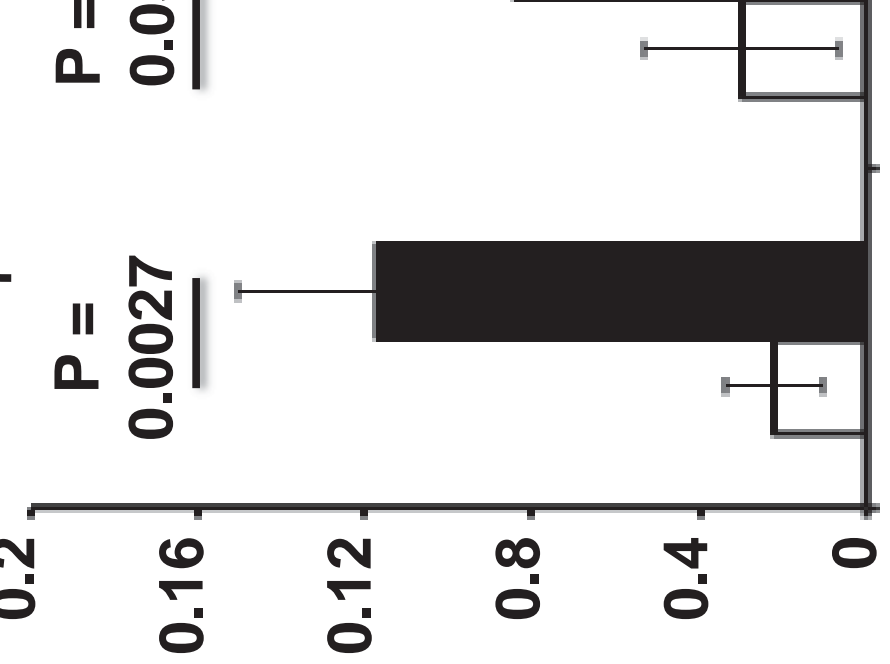

un!̣pəu

U!

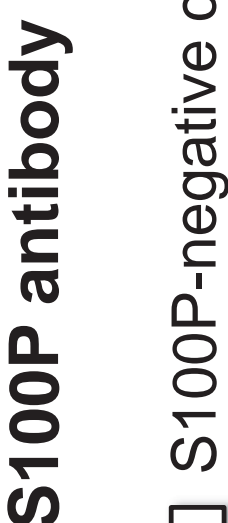

Кpoq!ฺu

\section{Кł! suәp ןeo!ndo}


8
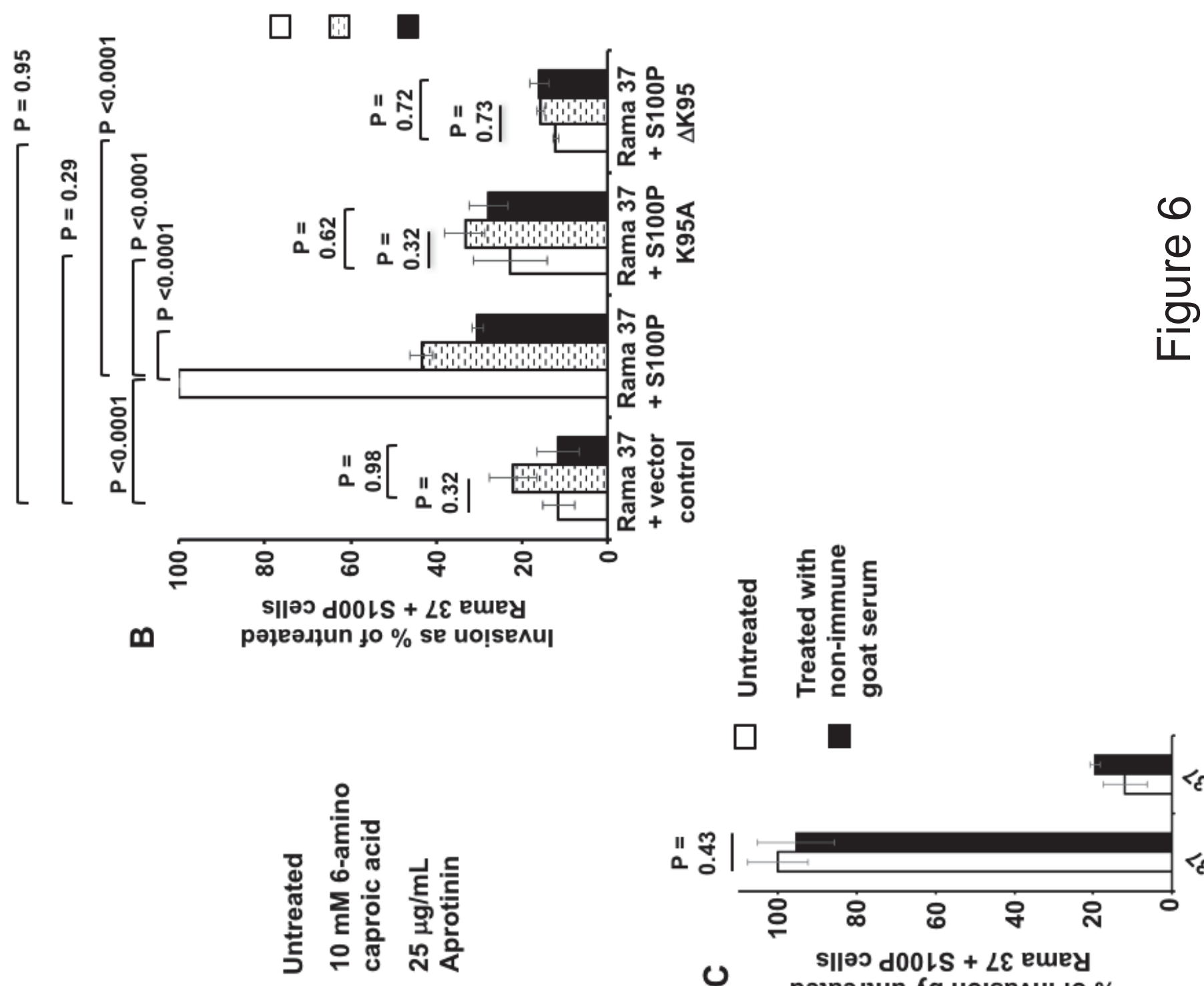

II ั่
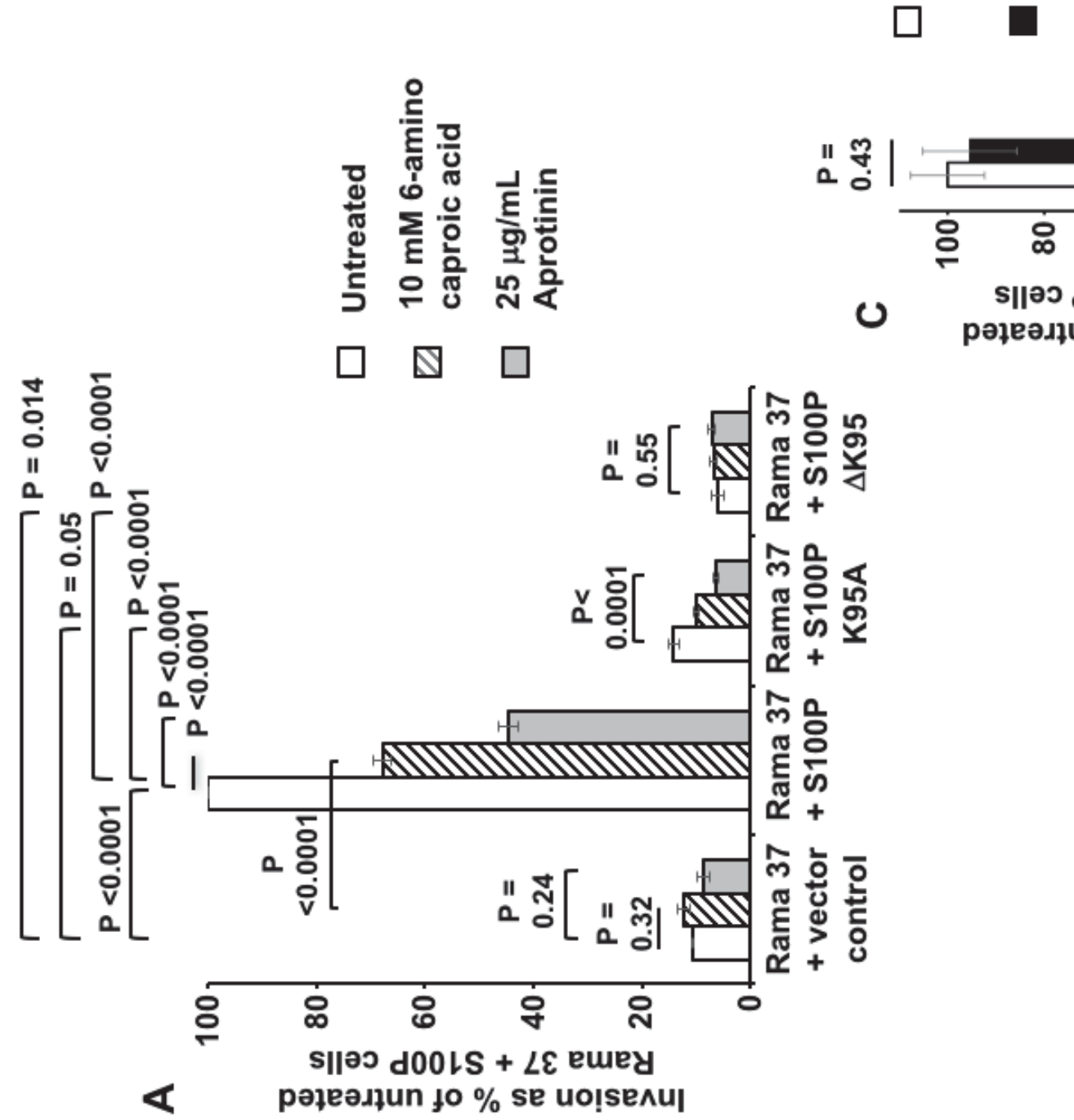


\section{Supplementary information 1. Expression of S100P in transfected Rama 37 cells}

Immunoblot of S100P protein levels in cloned cell lines and pooled cells of transfected Rama 37 cells expressing S100P wild type or mutants. Extracts of cells were separated by SDS polyacrylamide gel electrophoresis and blotted onto polyvinylidene difluoride (PVDF) membrane. The blot was incubated either with anti-human S100P antibody (Panel A) or with anti-actin antibody (Panel B) as a loading control. Bound antibodies were detected by chemiluminescence with HRP-conjugated secondary antibody. Clones and pools of cells transfected with expression vector containing cDNAs encoding S100P proteins contain similar levels of S100P protein, whereas the parental untransfected cells and cells transfected with empty expression vector contain levels of S100P protein undetectable by immunoblotting.

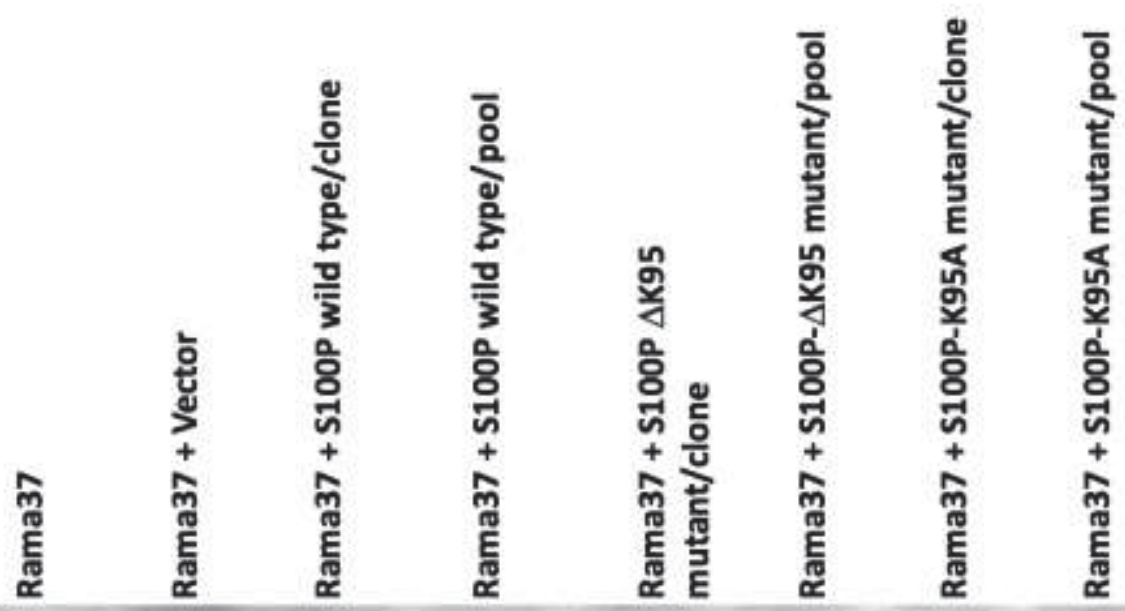

A

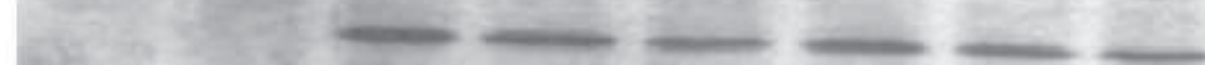

B 


\section{Supplementary information 2. Purification of recombinant S100P}

Wild type S100P protein was expressed in BL21 (DE3) E. coli cells (as described in Materials and Methods) and samples were collected at each stage of purification: following cell lysis and centrifugation (Supernatant), passing of lysate through a HisTrap column (Flowthrough), elution of bound protein from the HisTrap column (HisTrap elution), removal of His-tag using a thrombin-agarose column (Thrombin column elution fractions) and final clean-up using a Superdex ${ }^{\circledR} 75$ gel filtration column (Gel filtration fractions). The samples were subjected to SDS polyacrylamide gel electrophoresis and the gel stained with Coomassie Brilliant blue stain to visualise the proteins.
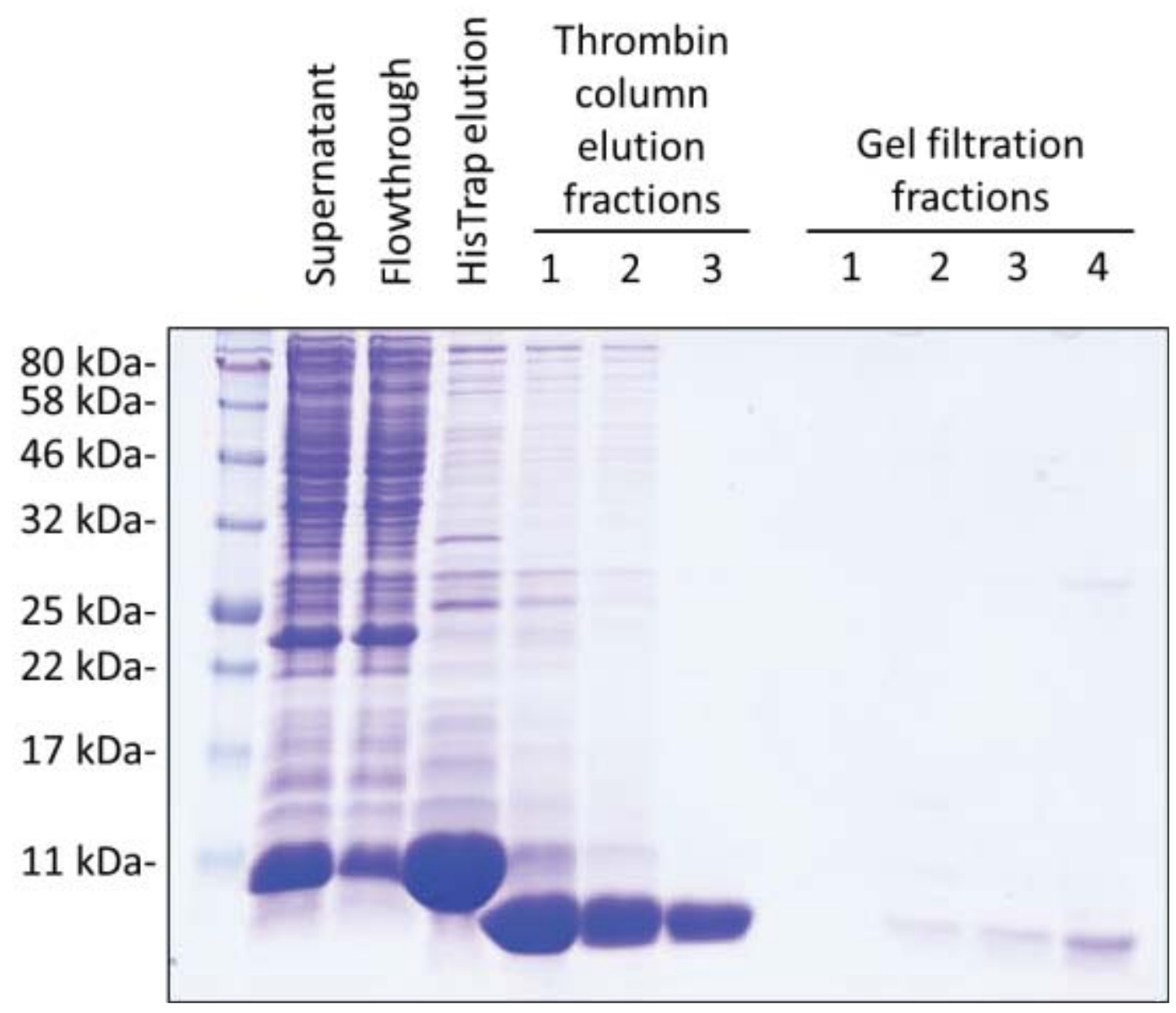


\section{Supplementary information 3. Size Exclusion Chromatography-Multi-Angle Light Scattering of wild type and mutant S100P recombinant proteins}

Recombinant wild type S100P or mutant proteins were subjected to Size Exclusion Chromatography-Multi-Angle Light Scattering as described in Material and Methods. At both 500 and $50 \mu \mathrm{M}$ calcium, all three proteins contained $96 \%-97 \%$ dimeric form with only $3-4 \%$ of the protein in a higher, mainly tetrameric molecular mass form. At $500 \mu \mathrm{M}$ calcium, the mean molecular masses of the dimeric form for wild type, $\Delta 95 \mathrm{~K}$ and $\mathrm{K} 95 \mathrm{~A}$ mutant proteins were $19.9 \pm$ $\mathrm{SD} 0.3,19.5 \pm \mathrm{SD} 0.15$ and $19.5 \pm \mathrm{SD} 0.2 \mathrm{kDa}$, respectively, values that were similar to the molecular masses obtained at $50 \mu \mathrm{M}$ calcium of $20.0 \pm$ SD $0.2,19.2 \pm$ SD 0.2 and $19.4 \pm$ SD 0.1 $\mathrm{kDa}$. There was no evidence of monomeric S100P at either 50 or $500 \mu \mathrm{M}$ calcium ion concentration.

\begin{tabular}{|c|c|c|c|c|}
\hline $\begin{array}{c}\text { Protein } \\
\text { (Calculated } \\
\text { monomeric } \\
\text { mass Da) }\end{array}$ & $\begin{array}{c}\text { Conc'n } \\
\text { of Ca }\end{array}$ & $\begin{array}{c}\text { Dimeric mass (Da) } \\
\text { (\% total protein) }\end{array}$ & $\begin{array}{c}\text { Tetrameric } \\
\text { mass (Da) } \\
\text { (\% total protein) }\end{array}$ & $\begin{array}{c}\text { Pentameric } \\
\text { mass (Da) } \\
\text { (\% total protein) }\end{array}$ \\
\hline $\begin{array}{c}\text { S100P Wild } \\
\text { Type } \\
(10,400)\end{array}$ & $50 \mu \mathrm{M}$ & $19,597 \pm 181(96.7 \%)$ & $41,800 \pm 936(1.6 \%)$ & $50,481 \pm 1,286(1.7 \%)$ \\
\hline $\begin{array}{c}\text { S100P Stop } \\
\text { mutant } \\
(10,254)\end{array}$ & $50 \mu \mathrm{M}$ & $19,202 \pm 202(96.2 \%)$ & $39,397 \pm 840(3.8 \%)$ & - \\
\hline $\begin{array}{c}\text { S100P A } \\
\text { mutant } \\
(10,421)\end{array}$ & $50 \mu \mathrm{M}$ & $19,370 \pm 104(96.3 \%)$ & $41,390 \pm 1,420(3.7 \%)$ & - \\
\hline
\end{tabular}




\section{Supplementary information 4. Binding of S100P to Glu-plasminogen and tPA}

Binding kinetics of wild-type recombinant (r)S100P with Glu-plasminogen and tPA surfaces. Both Glu-plasminogen (A) and tPA (B) surfaces were prepared using amide-coupling, as described in Materials and Methods. Wild-type rS100P was injected at the indicated protein concentrations over the surface in a buffer containing $100 \mu \mathrm{M} \mathrm{CaCl}_{2}$. Experiments were run in duplicate, and the mean response values for each protein concentration are shown.

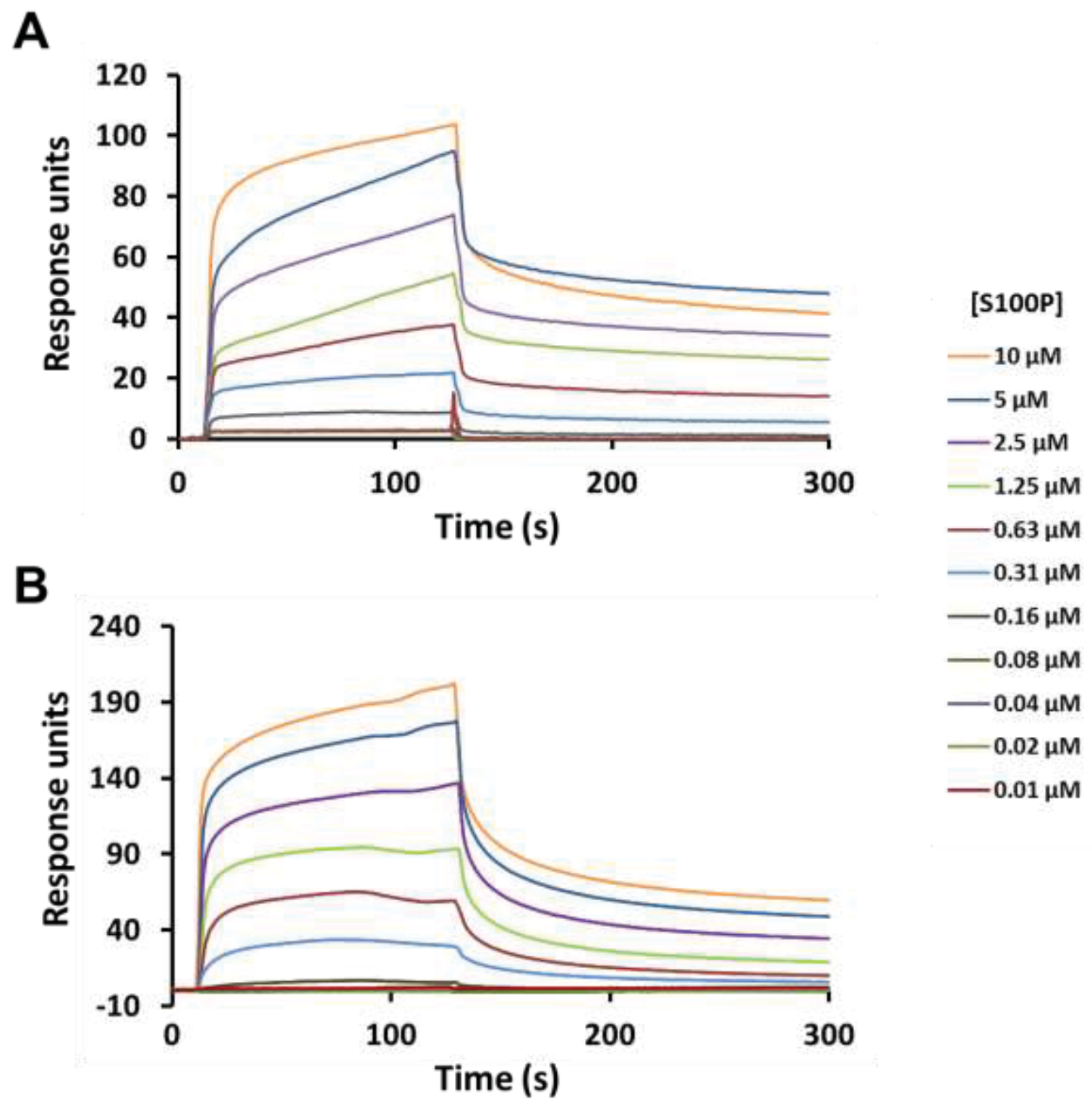




\section{Supplementary information 5. Assay for plasminogen activation in PBS buffer}

Multiwell tissue plasminogen activator (t-PA) activation assays were carried out as described in Materials and Methods in phosphate-buffered saline. The rate of accumulation of coloured plasmin product was monitored over a 2-hour period for incubations containing 0-7 $\mu \mathrm{g}$ recombinant human S100P. Plots of optical density against time squared gave straight-line graphs, which were used to compare the plasminogen activator stimulating activity of S100P proteins. A, B, Wild type S100P; C, D, $\Delta 95 \mathrm{~K} \mathrm{S100P;} \mathrm{E,} \mathrm{F,} \mathrm{K95A} \mathrm{S100P} \mathrm{(ug} \mathrm{=} \mathrm{\mu g).}$

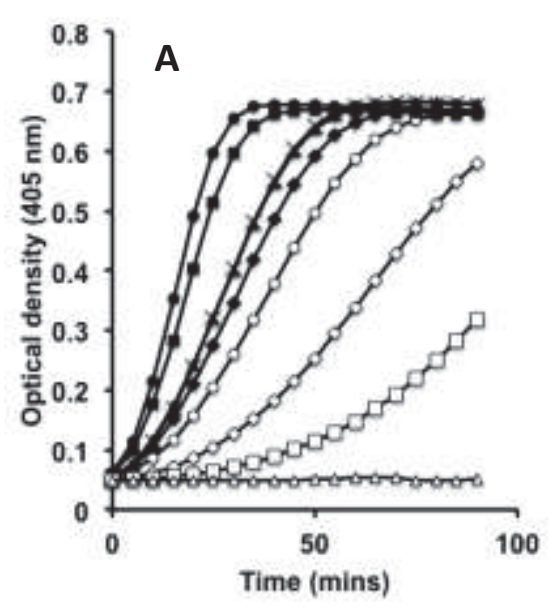

$\infty 0.1$ ug

$\infty 0.5$ ug

$\rightarrow-1$ ug

+1.5 ug

*2ug

-5 ug

$\rightarrow 7$ ug

$\rightarrow$ No S100P

$\rightarrow$ No t-PA
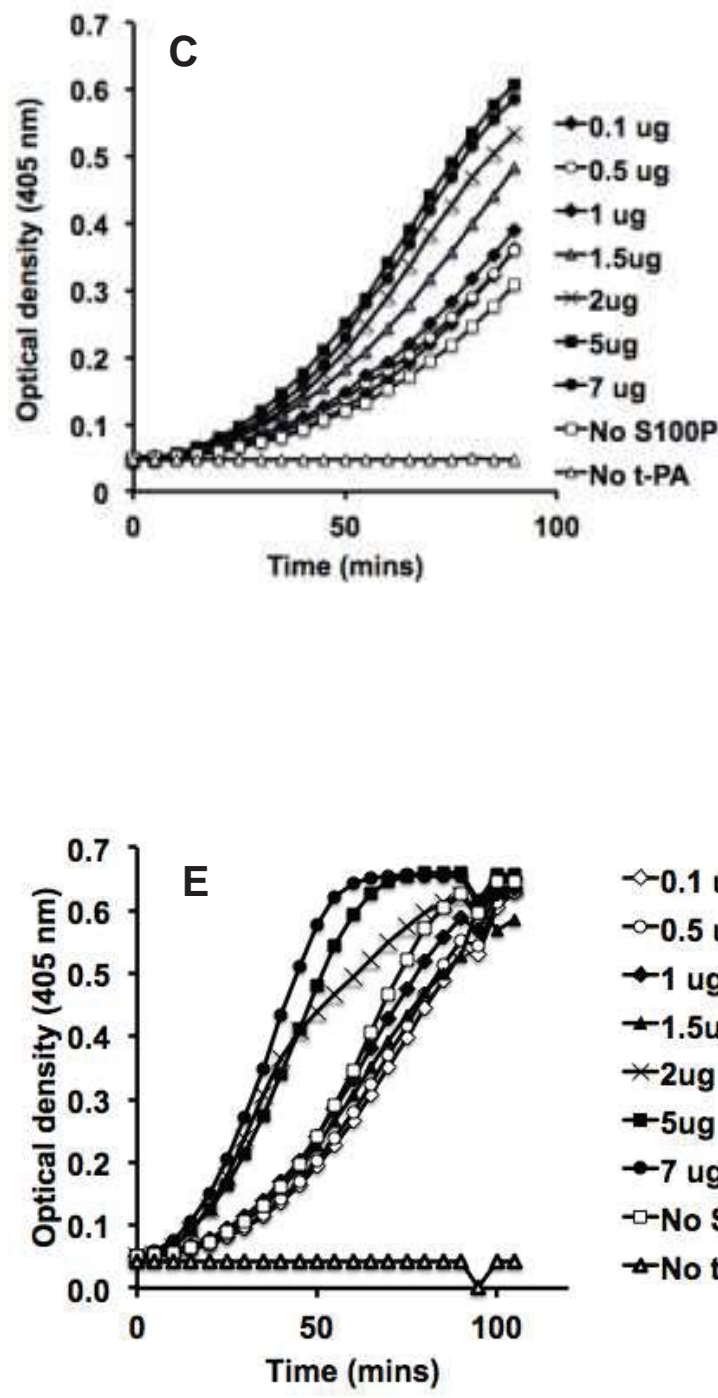

$\prec 0.1$ ug

-0.5 ug

$-1 \mathrm{ug}$

$-1.5 \mathrm{ug}$

*2ug

-5 ug

-7 ug

- -No S100P

$\triangle-N o$ t-PA
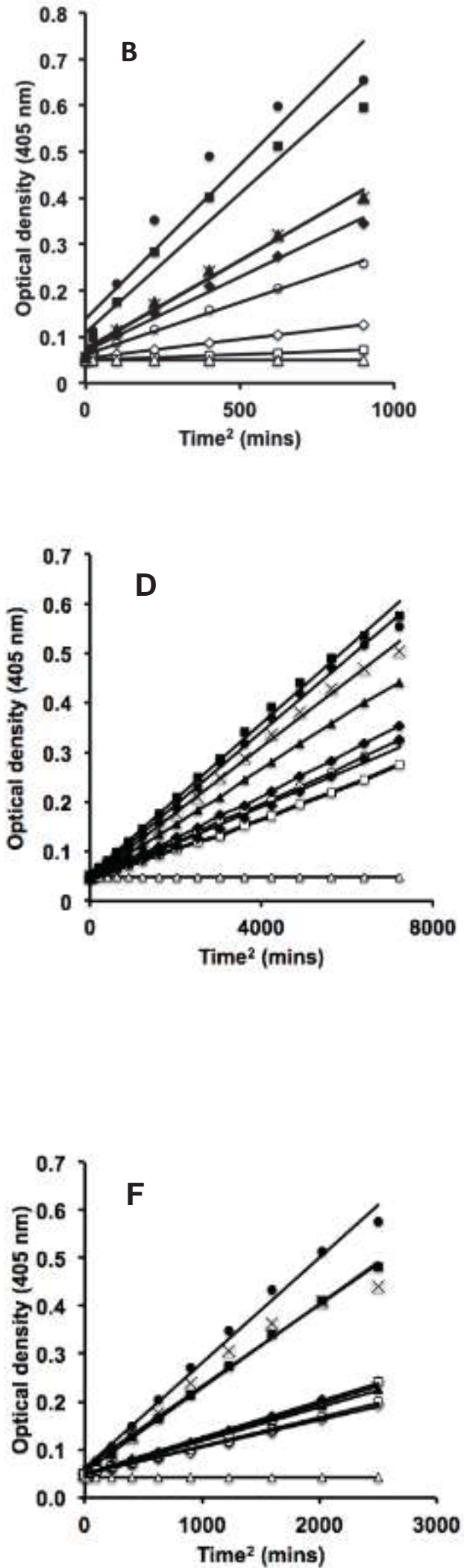


\section{Supplementary information 6. Invasion through Matrigel of cell clones and pools.}

Transwell invasion assays were carried out as described in Materials and Methods using 25,000 cells in the upper chambers and a 1-5\% gradient of foetal calf serum between the upper and lower chambers. Control cells comprised parental untransfected Rama 37 cells (Rama 37) and cells transfected with empty vector (Rama 37 + vector). Results are shown for a clone and pool of cells resulting from transfection with expression vector containing cDNA for: wild type S100P (Rama $37+$ S100P wild type), $\Delta 95 \mathrm{~K}$ (Rama $37+\mathrm{S} 100 \mathrm{P} \Delta 95 \mathrm{~K}$ ) and K95A mutants (Rama $37+$ S100P K95A). A final control of Rama 37 cells transfected with wild type S100P, but with 5\% foetal calf serum in upper and lower chambers, was included (Rama $37+$ S100P wild type equal serum). The cloned cell lines were used in the experiments described in the main body of the paper.

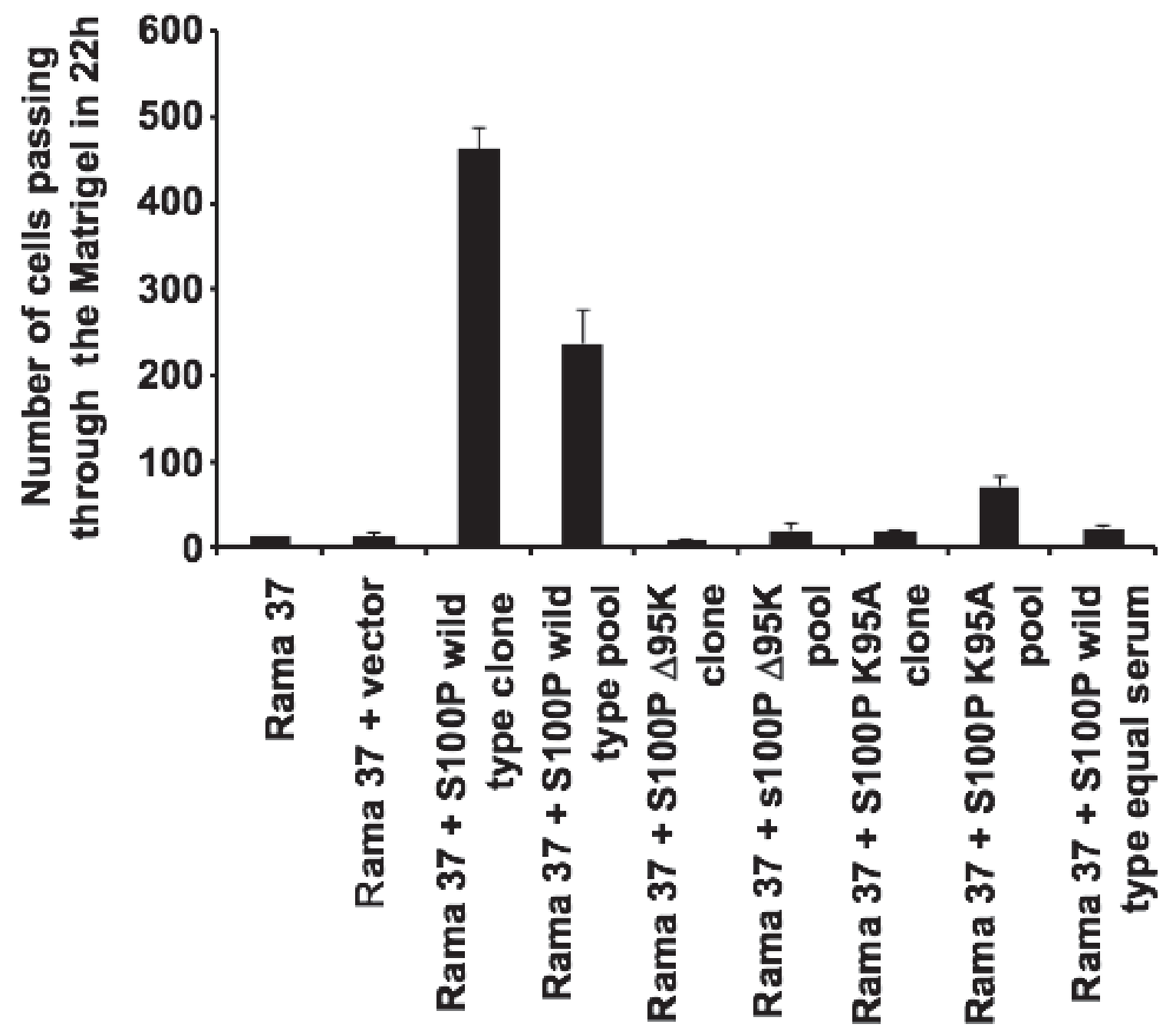




\section{Supplementary information 7. The levels of plasminogen and tPA mRNAs in Rama 37}

cells by polymerase chain reaction (PCR).

Plasminogen mRNA. PCR reactions were carried out in the absence or presence of cDNA isolated from control, S100P-negative, Rama 37 cells transfected with empty expression vector, or Rama 37 cells transfected with expression vector containing S100P cDNA and expressing S100P protein (Supplementary information 1) or with rat liver cDNA as a positive control. The plasminogen mRNA-specific primers were forward 5'-AAACACCTCATAGGCACAAC-3' and reverse 5'-CTTCAGGTTGCAGTATTCCC-3' and the PCR reactions consisted of 35 cycles of $30 \mathrm{~s}$ at $95^{\circ} \mathrm{C}, 30 \mathrm{~s}$ at $50^{\circ} \mathrm{C}$ and $90 \mathrm{~s}$ at $72^{\circ} \mathrm{C}$. The PCR mixture was subjected to agarose gel electrophoresis along with a $100 \mathrm{bp}$ ladder. No bands of amplification were detected in the cDNA from Rama 37-derived cells, either in the absence or presence of cDNA. However, in the same experiment under the same conditions, an amplified band of the expected size of $452 \mathrm{bp}$ was obtained from rat liver cDNA.

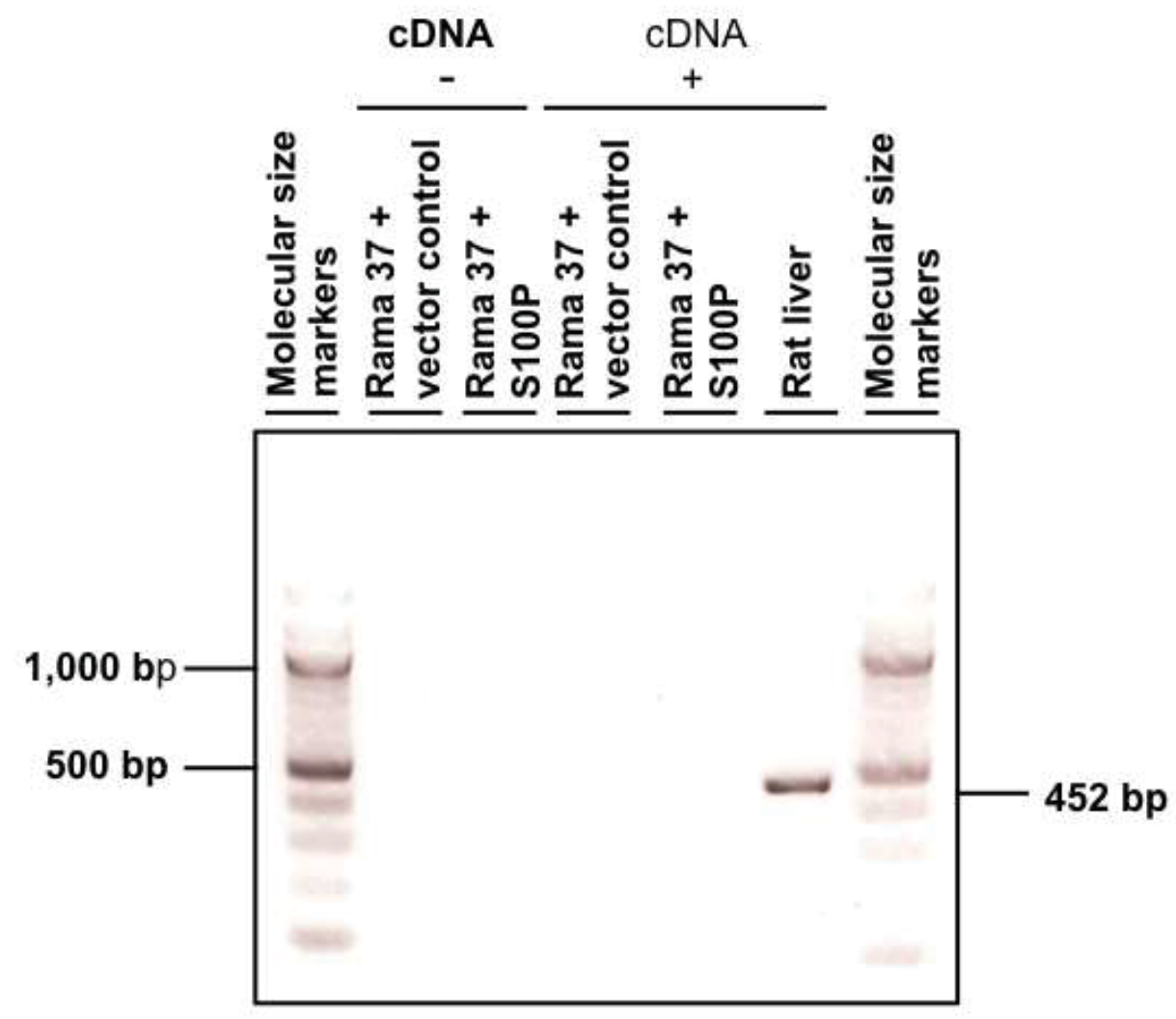

tPA mRNA. PCR reactions were carried out in the absence or presence of cDNA isolated from control S100P-negative, Rama 37 cells transfected with empty expression vector or Rama 37 cells transfected with expression vector containing S100P cDNA and expressing S100P protein (Supplementary information 1) or with rat kidney cDNA as a positive control. The tPA mRNAspecific primers were forward 5'-TGGCACCCACAGCTTTACCACATCCAAGG-3' and reverse 5'-CTCCTGAGTCACCTGGCACGCGTCATGG-3' and the PCR reactions consisted of 35 cycles of $30 \mathrm{~s}$ at $95^{\circ} \mathrm{C}, 30 \mathrm{~s}$ at $56^{\circ} \mathrm{C}$ and $90 \mathrm{sec}$ at $72^{\circ} \mathrm{C}$. The PCR mixture was subjected to agarose gel electrophoresis using a $100 \mathrm{bp}$ ladder. Bands of amplification of the expected size of 
$908 \mathrm{bp}$ were detected in the cDNA from Rama 37 cells and rat kidney, but there were no bands in the absence of cDNA.

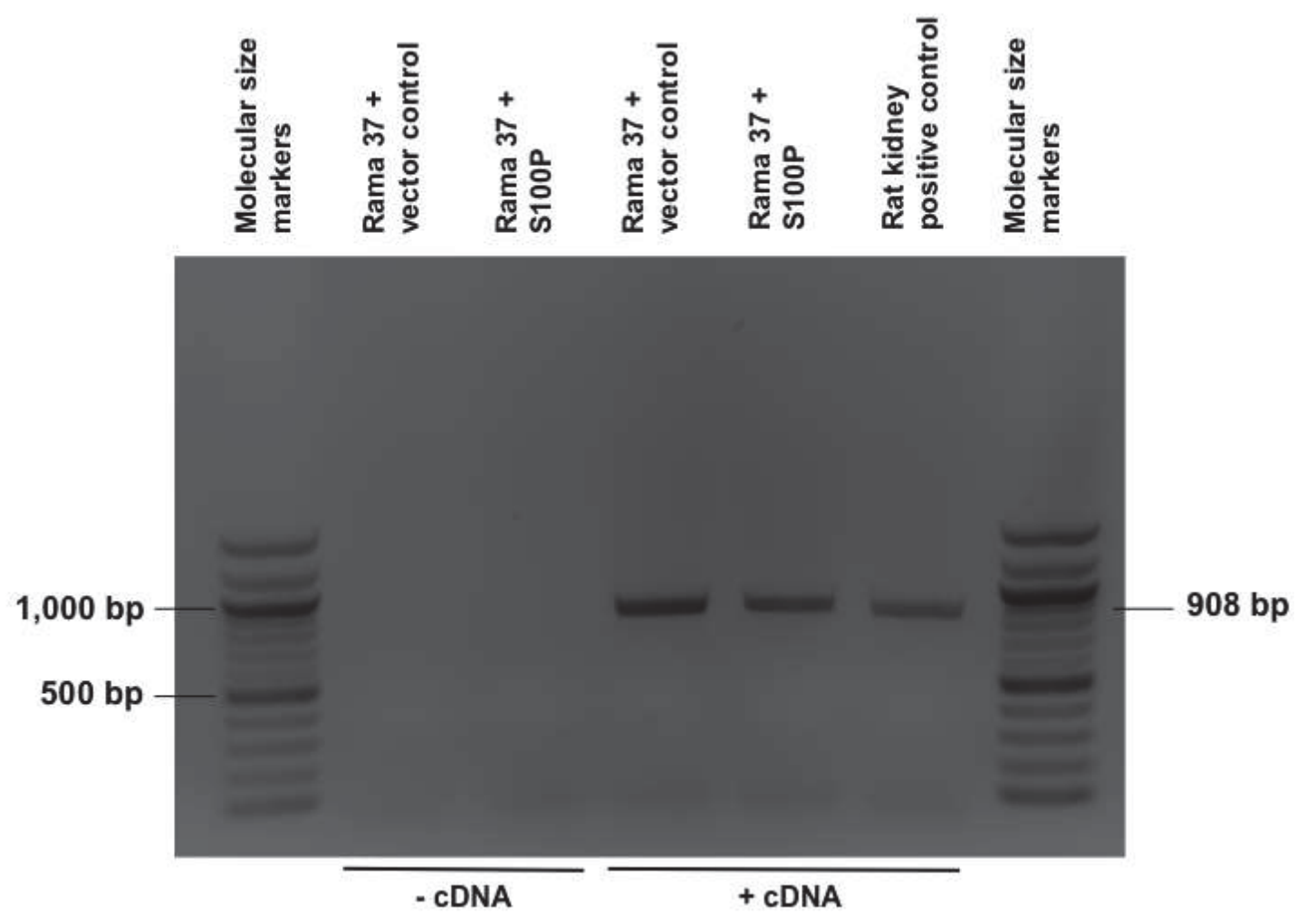




\section{Supplementary information 8. Annexin AII in Rama 37 cells}

Extracts of cell lines and pools expressing S100P and control S100P negative cells were cultured and extracts prepared for SDS polyacrylamide gel electrophoresis, as described in Materials and methods. The extracts were subjected to gel electrophoresis and Western blotting with antibodies directed against annexin AII (BD Biosciences) or non-muscle actin (Sigma). Bands corresponding to annexin AII $(36 \mathrm{kDa})$ and actin $(43 \mathrm{kDa})$ are shown for a pool of cells expressing the $\Delta$ K95 S100P mutant (Rama $37+$ S100P $\Delta$ K95 pool); control S100P-negative Rama 37 empty vector transfected cell clone (Rama 37 + vector control clone); a pool (Rama 37 + S100P pool) and a clone (Rama $37+$ S100P clone) of cells expressing wild type S100P; a clone of Rama 37 cells expressing the K95A mutant of S100P (Rama 37 + S100P K95A clone). All cells expressed annexin AII protein.

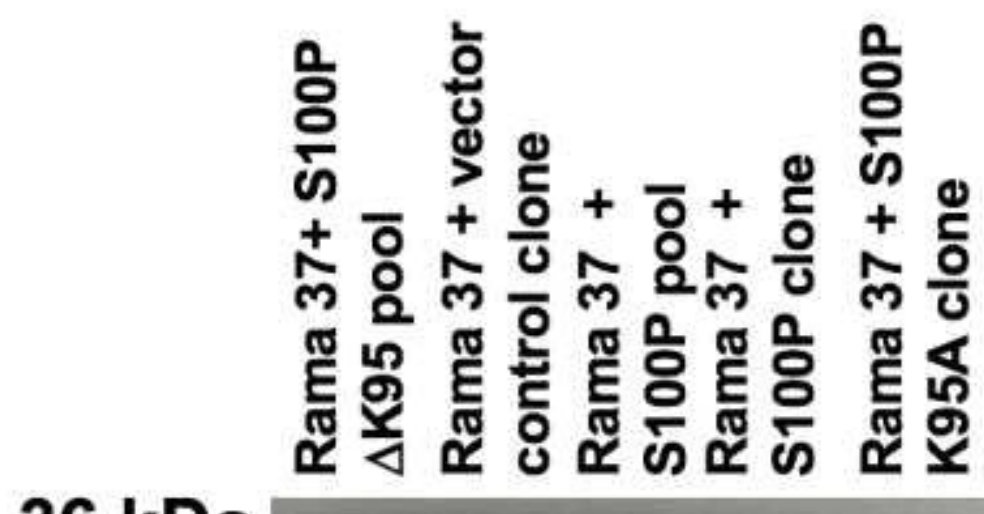

